\title{
Landscapes between Heaven and Hell in the Old English Guthlac Material
}

\author{
Verena Klose
}

\section{Introduction}

Nature and more specifically landscape is a space that humans inhabit and share with others, such as animals and plants as well as other products and features of the earth. Naturally, the relationship between the individual and the physical world is influenced by various factors that are subject to change. In any case, one expects that the experiences humans have in and with the environment are represented in the cultural images of nature that they create. Accordingly, literature functions as a form of artistic expression that conveys attitudes and behaviours towards the natural world. ${ }^{1}$ The art historian W. J. T. Mitchell argues that landscape can be "a medium of exchange between the human and the natural, the self and the other" while it constitutes at the same time "a natural scene mediated by culture" (Mitchell 5). This means that there is never an experience of nature that is purely sensory or physical; the perception of the landscape is also influenced by the cultural meanings and values that are imprinted on it. These impressions are based on any previous contact with and exposure to nature that is preserved either as

\footnotetext{
1 This is essentially the widest definition of ecocriticism as a literary theory that is interested in the "study of the relationship between literature and physical environment" (Glotfelty xviii), especially in the mutual influence between man and nature. One ecocritical premise is to not measure landscape by its usefulness or to see it solely as a potential object of aesthetic pleasure, but to recognise it as an independent entity with an intrinsic value and dignity
} 
individual experiences or as the understandings of a whole group of people as they are passed down across generations.

Religion is certainly an important part of this mediating culture, especially in the Middle Ages. It has not only a significant impact on the recognition of any intrinsic value of any non-human life, but also on the way that humans are aware of the world and their standing in it. For instance, many have argued that the Abrahamic religions with their belief that the earth was created by God so that humanity could inhabit it contribute to the anthropocentric perspective on nature that is predominant in Western society today. If one examines the Bible as the cultural artefact that is the basis of the Judaeo-Christian religions, one finds that it is concerned with the concrete landscapes inhabited by people as well as with metaphysical places like heaven and hell. However, these metaphysical landscapes are not merely abstract concepts but notions that are often described in naturalistic terms; one example of this would be the depiction of Paradise as the Garden of Eden which is the embodiment of a perfectly delightful and harmonious place that leaves nothing to be desired. Likewise, those settings are crucial to the human self-awareness as creatures placed within God's creation who simultaneously affect and are affected by it. In her study Representations of the Natural World in Old English Poetry, Jennifer Neville states that "humanity is first of all situated both morally and spatially between heaven and hell and is thus subject to forces from both" (23). This paper will argue that the same can be said of the landscapes that they inhabit.

The surviving texts about Saint Guthlac of Crowland and his dwelling-place in the Fens constitute an important source for the early history of East Anglia and the creation of this local saint's cult. The main source for his cult and the accounts about him is the Anglo-Latin saint's life Vita Sancti Guthlaci by the monk Felix. There is little information about the author himself, although it is assumed that he lived and worked in East Anglia (Colgrave 16). In the Prologue of his Vita, Felix dedicates the text to king Ælfwald who was the ruler of said kingdom from 713 until 749 (Gonser 15-19, Colgrave 15). After the consideration of intra- as well as extradiegetic evidence, Colgrave dates the Vita between 730 and 740 (19).

The Anglo-Latin Vita inspired several other works on the saint. One of them is an Old English translation that can be found in Cotton Vespian D. xxi and which was edited in 1909 by Paul Gonser. The Old English version of this Vita is not a close translation, but it follows the narrative outline of the Latin text. Another fragment consisting of two slightly altered chapters (sections four and five) from the The Life of St Guthlac is included in the Vercelli Book as Homily XXIII (Scragg 383-94). Additionally, there are several anonymous epitomes and also a Middle English translation of the Life (Colgrave 20-25).

The two poems Guthlac $A$ and Guthlac B appear in the Exeter Book, which is dated to the latter half of the tenth century (Roberts 12). The poems were composed in Mercia, most likely by different writers. Even though it is not possible to 
determine the exact extent to which the authors made use of the saint's life in their writing process, it is generally agreed that the Guthlac B poet follows the Vita more closely and uses especially the fiftieth chapter as a basis for the poem, which focusses on the saint's death (Roberts 36). The Guthlac A poet, on the other hand, gives a more general account of the saint's life that seems to be informed by the Latin source but alludes only modestly to its main features (Roberts 19-23, Colgrave 20).

The texts on the English saint Guthlac offer valuable material for a discussion about morally charged landscapes, because the protagonist is not a regular human being but in his role as a saint he functions as a mediator between a morally ambiguous human nature and the deity. In his dwelling on earth, Guthlac encounters both divine and demonic settings, and the natural world does not remain unaffected by his presence. In literature, the portrayal of the outer world is oftentimes closely connected to the inner world of the literary characters. For instance, the landscape often serves as a generic background that is taken for granted, as a stage on which the protagonist has to face their personal trial, as a threatening and overpowering force, or even as an aesthetically pleasing object. Therefore, it is important to analyse landscape not only as an independent entity that is preserved in textual form, but also as a medium that can be used to discuss and project moral issues. This paper will focus on the mediation between the natural world and Guthlac as a man who exposes himself to a specific external setting as an act of devotion to God in order to pursue spiritual growth and achieve absolute purity of the soul. For this, there will be a concise overview of the textual portrayal of landscape as it can be found in the Vita Sancti Guthlaci by Felix, the Anglo-Saxon translation of this life, and in the two poems Guthlac $A$ and Guthlac B. A survey of the literary and theological concepts that inform the texts is essential for the analysis of landscape as a cultural image that mediates between nature and humankind. This paper's emphasis will be on the most distinctive landscape features found in the poems and how they relate to some of their major themes, namely spiritual pilgrimage, exile, and the cosmic battle between good and evil, as well as to the abovementioned metaphysical landscapes of heaven and hell.

\section{Fens, Deserts, and Mountains: Locating Landscapes in the Guthlac Material}

The Portrayal of Landscape in the Guthlac Material

Felix's Vita documents the spiritual journey of a man of noble birth who spends the first part of his life serving as a soldier and establishing himself as a reasonably successful military leader. One night, he is overcome by an existential crisis which leads to his conversion and entrance into ecclesiastical life. After taking the 
monastic vows and spending two years at the monastery of Repton, he decides to leave the religious community in order to pursue life as a hermit in the wilderness. Guthlac settles on an island that is situated in the fens and builds his hermitage there. Based on contemporary events described in the text as well as references to ruling kings that can be verified with other historical sources such as the AngloSaxon Chronicle, one can determine 714 as the year of his death (Roberts 1).

The place that he chooses as his settlement is depicted in various ways in the Guthlac material. In the Vita, Felix describes the region to which Guthlac decides to retreat as "inmensae magnitudinis aterrima palus, nunc stagnis, nunc flactris, interdum nigris fusi vaporis laticibus, necnon et crebris insularum nemorumque intervenientibus flexuosis rivigarum anfractibus" (Colgrave 86). ${ }^{2}$ This fen is located near Cambridge, between the River Granta and the North Sea. Furthermore, Felix presents the marshlands as a vast and far-stretching desert (vastissimus heremus, Colgrave 86; spatiosus heremus, Colgrave 88) with wild places (inculta loca, Colgrave 86). On his search for an adequate spot, Guthlac consults the natives of the region, who point him towards an island called Crowland in the middle of the marsh. He even has to travel by boat in order to reach the isle, which shows that it is an intensification of the aforementioned vast and wild region. It is not only located in "the more remote and hidden parts of that desert" (89) but due to its closeness to the river and sea also surrounded by water or at least distinctively muddy moors, which adds the sense of a liminal borderland (89). The inhospitality of the location is further illustrated by the previous attempts of occupation that were all in vain: many have tried to live on the island but eventually they all had to give up due to the unknown monsters of the desert ("incognita heremi monstra," Colgrave 88) and the terrors of various shapes ("diversarum formarum terrores," Colgrave 88) that haunted the place.

Thus main attributes of the territory are not only its concrete topography (size, natural features) but also the lack of human cultivation that corresponds to the threatening unknown and the "monsters" it emanates. The uncultivated conditions in this waste land are expressed by the term incultus which is used to describe the fens (Colgrave 86; 88). The Dictionary of Medieval Latin from British Sources gives several meanings for the word heremus, which is used whenever Felix talks about the setting; among them are "desert," "wilderness," and "waste land" (Howlett s.v. heremus). It is also used to refer to a solitary life and the eremitic life in general. While a desert is usually imagined as a dry, barren area of land that is characteristically sandy, hot, waterless, desolate, and mostly without any vegetation, this vernacular version is composed of features that are representative of the local English landscape, but shares the notion of desolation and wilderness with the conventional desert. Therefore, Felix establishes the marshlands as an English version of

2 "A most dismal fen of immense size ... now consisting of marshes, now of bogs, sometimes of black waters overhung by fog, sometimes studded with wooded islands and traversed by the windings of tortuous streams" (ch. 24: Colgrave 87). 
the desert by referring to the Fens as a desert while giving a description of a native landscape that is characterised by marshes, bogs, various waters, and fog. All in all, these factors contribute to a place that offers the ideal conditions for Guthlac's solitary retreat. Accordingly, he begins to dwell on the island and builds himself a hut in the side of a tumulus ("mound," Colgrave 92).

The Old English Life of St Guthlac mostly follows the Latin source in its portrayal of the environment that Guthlac discovers. It also emphasises that it concerns a "fen of immense size" ("fenn unmætre mycelnysse," Gonser 113) and draws attention to the general "vast wilderness" (widgill westen, 113) that defines the land. The translation also makes use of authentic knowledge of the place and illustrates the fen's size by referring to specific place names. In addition to the River Grante, which is already mentioned in Felix's Vita, it refers to the nearby city Granteceaster and describes the moorlands as extending from there to the North Sea (Gonser 113). Furthermore, the translation expands on the marshland's distinct elements: "Pær synd unmæte moras, hwilon sweart wætersteal, and hwilon fule earipas yrnende, and swylce eac manige ealand, and hreod, and beorhgas, and treowgewrido" (Gonser 113). ${ }^{3}$

Both Felix's Vita and the Anglo-Saxon translation agree on the moor as a setting that is characterised by the juxtaposition of water and earth, which manifests itself in its bogs, streams, and islands, but the Life also notes reeds, hills, and thickets. While it can be argued that the "thickets of trees" echo the "wooded islands" in Felix, the reeds and hills are definitely an addition of the Anglo-Saxon text. Especially the beorgas are of significance throughout the text, as the following analysis will show.

Concerning the island, its position is described as "on middan pam westene ... pæs foresædan fennas, swyðe digle" (LSt.Guth. 114). ${ }^{4}$ The reasons that are given for the place's lack of inhabitation are the same as in Felix's Vita: no man was able to endure its "solitude" (annys, 114), seclusion, and the terrors ("menigfealdum brogum and egsum," 114) that are associated with the place. Nevertheless, these bleak circumstances do not keep Guthlac from settling there, "betwyx pa fenlican gewrido pæs widgillan westenes, pæt he ana ongan eardian" (LSt.Guth. 115). ${ }^{5} \mathrm{He}$ finds a hlaw mycel ("great mound," 118) with a watersead ("water-pit," 118) on which he then erects a house.

In comparison, the two poems do not speak in great detail about the specifics of Guthlac's settlement. This is understandable in the case of Guthlac B, as this text mostly skips the beginning of the saint's settlement in order to focus on the last

\footnotetext{
3 "There are immense moorlands, sometimes black stagnant water, sometimes foul water-streams flowing, and also many islands, and reeds, and hills, and thickets of trees." References to the AngloSaxon Life of Saint Guthlac follow the edition by Gonser. Translations of the Old English primary texts are my own, unless otherwise indicated.

4 "In the middle of the wilderness of the fens mentioned before, very secret."

5 "Among the fenlike thickets of that vast wilderness, which he began to inhabit alone."
} 
part of the saint's life, especially on the events and temptations before his death. Still, the poet makes a point of emphasising the wilderness (westen, 899a; 935a ${ }^{6}$ ) of the dwelling-place that the holy man has chosen for himself. Moreover, the text does not locate the setting on an island until the very end: in Guthlac's dying moments, "beofode pæt ealond, / foldwong onsprong" ("that island trembled, the earthly plain burst forth," 1324b-26a) and his servant travels by boat to deliver the message of the hermit's death to his sister (1326a-43b). According to this section, which is charged with imagery referring to a water journey, the island is not merely a dry spot in a marshy region, but rather surrounded by the (open) sea and therefore strictly separated from the mainland. For instance, the portrayal of the servant's journey includes a wide range of kennings for the word "ship": waghengest ("sea-steed," 1329a), waterpisa ("water-rusher," 1329b; this term can denote either a ship or a whale), brimwudu ("sea-wood," 1331b), lagumearg ("seasteed," 1332b), and harnflota ("wave-floater," 1333b). In this situation, both the island and the sea convey a sense of insecurity and mobility that is opposed to the sondlond ("sea-shore" or "sandy land," 1334b) that is "grond wið greote" ("ground with dust," 1335a) and therefore suggests stability and the security of a harbour. This can be seen as a reflection of the North Sea which is alluded to in both prose versions of Guthlac's hagiography. Although the poet does not specifically state the proximity to the sea, he apparently presumes a certain basic knowledge of the saint and a familiarity with the location of his residence.

Guthlac A, on the other hand, does not mention the island at all, but concentrates on the beorg and Guthlac's heroic and saintly actions in the wilderness. At the beginning, the poem explicitly introduces the concept of voluntarily leaving the safety and comfort of human civilisation: "sume pa wuniað on westennum / secað and gesittað sylfra willum / hamas on heolstrum" (81-83a).7 Jennifer Neville argues that this choice of habitat distinguishes the saints from people who are engrossed in worldly matters such as wealth; in Guthlac's case, that he chooses to live as a hermit under such dire conditions is even a result of his "holy condition" and "inner saintliness" (125). This concept of a self-imposed exile comes into practice when the former soldier begins to live on his own in a beorgsepel ("mountain-dwelling," 102a) and to defend his bold on beorge ("building on the hill," 140a) despite the hardships that await him there. Moreover, the specific place where he erects his home is described as a beorg on bearve ("mountain in a grove," 148a), which is certainly reminiscent of the woods mentioned in both Felix's Vita and the Anglo-Saxon Life.

The omission of a specific scenery in the poems results in a rather generic description of the landscape in the poetic accounts in comparison to the prose texts. While they appear to be not overly concerned with the outside world as a scenic

\footnotetext{
${ }^{6}$ All quotations of the Guthlac poems are taken from Jane Roberts's edition.

7 "Some then dwell in the wilderness, they search for and settle down in homes in the darkness by their own will."
} 
framework, they do not depict the environment as something that is essentially evil or sinister in itself either. This is true for both poems; for example, the mountains are described as grene beorgas (232b) in Gutblac $A$, a rather pleasant and peaceful image that is a stark contrast to the wracmacgas ("devils," 231b) that used to inhabit it. The focus is more on the impact that the environment has on the saint, as well as the creatures that are part of the natural setting and the way that they interact with the hermit.

A theme that the two poems have in common is the outstanding presence of the beorg. Among others, Hugh Magennis identifies the hill that the saint settles on as the "key feature" of the physical setting in the Guthlac poems which should be understood in spiritual and symbolic terms (181-82). The analysis of the beorg as a crucial element of the poetic landscape has been the object of academic discussion for a long time. While the Latin Vita as well as the Anglo-Saxon Life are welldefined in their use of the words tumulus and blaw-both signifying "mound"-for the site that Guthlac decides to inhabit, neither of the poems follows this notion. Thus the Old English beorg is often seen as a rather ambiguous term that can be understood in multiple ways. Laurence K. Shook argues that the translation of beorg as a "hill" or "mountain" is inconsistent with the geographical setting of the Crowland fens and should therefore rather be rendered as "burial mound" or "barrow," following the Latin hagiography. In its symbolic mode, the barrow denotes attributes that are important in the spiritual Christian life: "grace, struggle, the Will of God, temporal perseverance, and eternal salvation" (10). In contrast, Paul F. Reichardt proposes that "mountain" is in fact the most appropriate interpretation, because "this reading creates important symbolic associations which would have reinforced the poem's themes in the minds of its original AngloSaxon audience" (331). Hence, Reichardt links the beorg to an overarching and comprehensive symbolic pattern: he finds that it resonates with the "mount of saintliness" as it can be found in early Christian theology so that a contemporary audience would have interpreted Guthlac's conquest as the symbolic ascent of a mountain that would transform him into a holy person (336). For him, the mountain is both a geographical setting and a symbol of "interior spiritual achievement," because it indicates the state of ascetic perfection that Guthlac is able to reach (335). Karl P. Wentersdorf counters that although the mountain is a widely used symbol in both Christian and heathen mythology, this reading ignores the identification of the beorg as a tumulus in Felix's Vita (135). For him, Guthlac's claim and defence of the mound not only represents his individual struggle and "spiritual war against his personal demons" but also the Church's endeavour to fully convert England and to cast out any "lingering remnants of heathendom" (136).

In any case, all four texts agree on the distinctiveness and peculiarity of the location that Guthlac selects for his dwelling. Both an island and a mountain, be it a natural elevation or one that was created by human intervention, are topographical 
landmarks that stand out in the landscape. They also enhance the monk's eremitical status, because they intensify the isolation he voluntarily seeks out. The island, for one, attracts attention as the only dry spot in surroundings that are characterised by their wet and muddy nature. The fact that Guthlac needs a boat to get there shows that the place is not easily accessible but rather separated and shielded from the world. This not only complicates access to the island, it also means that it is harder for the saint to keep in touch with the worldly matters that affected his ordinary life before the hermitage. In the case of a hermit, this obviously constitutes an advantage, because it enables a categorical withdrawal from the earthly community. The same applies to a mountain: first of all, it may be approachable by foot, but the route of ascent may also prove to be difficult and demanding. At the same time, any person who undertakes the climb or walk to the summit of a mountain is automatically exalted in a way. In addition, they are granted a view that exceeds the perspective that one has on the ground in its extent, which is why mountains were often used as preferred location for the strategically convenient erection of buildings, both secular and religious.

Saintly Dwellings: Christian Asceticism in the Desert and its Relation to Guthlac

Guthlac's departure into a self-imposed exile in the marshlands and the subsequent events in his life as an anchorite are the main focus of the texts at hand. The outset of his journey as a saint is similar to those of his holy predecessors, which can be traced in hagiography as well as in the Bible. The idea of leaving one's home and the associated comforts behind in order to expose one's body and mind to the afflictions of wilderness and loneliness for the benefit of gaining wisdom and spiritual strength is a common trope in religious writing. The destination of the monk's departure is also part of a wider hagiographical tradition: as stated before, both Guthlac poems call the English marshland westen, which can be translated as both "wilderness" and "desert." Therefore, one can analyse the fens and their literary representation as the portrayal of an external setting that is equivalent to a desert.

The desert as a specific geographical setting has a unique role in the history of Christianity and it figures in both the Old and the New Testament. If one takes the narrative of Exodus as an example, the desert functions mostly "as a place of encounter with God who makes his presence known through revelation, chastisement, nourishment, and protection" there (Rapp 94-95). The Israelites are led by Moses through the desert for forty years until they reach the Promised Land; thus the desert functions as a border between the original and the final state, in both a geographical and a spiritual sense, as the people not only travel from Egypt to the Promised Land, but also focus on their relationship with their creator. This makes the desert a "locus of transformation and transition to a greater unity with God" (95). In the New Testament, the desert features as the location of several significant narratives. For one, John the Baptist announces the coming of Christ 
in the desert of Palestine. More importantly, Jesus spends forty days in the desert after his baptism. He spends his time fasting, praying, and contemplating, and is tempted by the devil who takes him "in montem excelsum valde" ("up into a very high mountain") and offers him all the kingdoms of the world that he can see from that perspective (Matt. 4:8-10). ${ }^{8}$ In Guthlac $A$, the monk is also lifted up high in the air by demons and they give him the ability to observe the actions of other men in the monasteries who do not live according to God's law (Guthlac $A, 412$ 26), with the intention of breaking his spirit and persuading him to give up his quest as a hopeless case. But both Jesus and Guthlac pass this test and overcome the demons that torture them. The biblical account of Christ's temptations is not only the precondition of his later life as a healer and preacher, it also establishes the desert as a space in which evil spirits can potentially take up their residence.

The aspirations of hermits and monks in Late Antiquity who chose the desert as their dwelling-place are a reaction to both the Old and the New Testament, because they wanted to "reenact the experience of the Exodus and ... bring alive God's promises to his chosen people given by Jesus" (Rapp 94). The desert myth as it was constructed in early Greek hagiography imagines it as a place where Christians could transform their own souls by living an ascetic life as well as their surroundings by battling against the resident demons (98-99). This gives them the opportunity to "participate and contribute to the history of Salvation" (103). The desert in its inhospitality and dissociation from everything worldly enabled the monks to create a space in which they could prove themselves and their devotion as God's servants. Both the notion of escapism and the major challenge of facing the devil in his domain are part of the fundamental experience of God that the anchorite can find in the desert, which then allows him to lead an authentic life (Schulz and Ziemer 19-23). Furthermore, the constant effort for spiritual growth that all Christians undertake after their baptism can be seen as analogous to the Exodus of the Israelites through the desert. In this understanding, the whole world is interpreted as a desert, in which the individual Christian leads the life of a pilgrim on his or her spiritual journey to heaven (Rapp 102-03).

In the case of Guthlac, the textual accounts reveal a familiarity with several hagiographical writings, most importantly Athanasius's Vita Antonii. Saint Anthony settled in the Egyptian desert in the second half of the third century; he is generally considered the first monk who went into the wilderness in order to live as an ascetic. Shortly after Anthony's death in 357, Athanasius began to write the biography of his life, which became one of the most important documents about the solitary ascetic life of early Christian monks (Meyer 3-15). Therefore, one can assume that Felix was familiar with this well-known text. Especially the structure of his Vita bears resemblance to the Vita Antonii: both Guthlac and Anthony come from a wealthy and privileged background before they take their monastic

${ }^{8}$ Except where otherwise indicated, biblical quotations follow Weber for the Latin and DouayRheims for the English (The Holy Bible, Translated from the Latin Vulgate). 
vows. Anthony's progress as an ascetic monk is symbolised by his change of location and scenery; his retreats become increasingly reclusive the more he advances as a spiritual being (Schulz and Ziemer 36-37). Another outstanding similarity to Guthlac's life is the presence of a summit: the Vita Antonii specifically mentions both an actual hill (Mount Kolzim) as well as the concept of an "inner mountain" that is to be conquered and climbed (Schulz and Ziemer 367; Meyer 4-7). Correspondingly, the hill that figures prominently especially in the poems can be identified as a feature of eremitical hagiography, because hills or mountains often dominate the landscape in these writings (Magennis 184).

\section{Guthlac's Surroundings and Their Moral Quality}

\section{Divine Light and Paradisal Places}

Apart from the concrete landscape of East Anglia as it is depicted in the Guthlac material, the immaterial landscapes of heaven and hell also plays an important role. The premise that these settings can either be described with visual imagery that is based on the natural world or with abstractions that often already carry a moral judgement in them applies to both.

The association of light with heaven and joy is based on both theological and literary conventions. For one, light is a feature of the locus amoenus. The locus amoenus ("pleasant place") is a literary motif in Classical Western literature that conveys an idealised notion of a landscape that is characterised by tranquil and amiable nature imagery. It embodies the idea of a cultivated and ordered landscape which is typically safe and comfortable for the dweller. The setting is often described with the help of stock images, such as woodlands, a waterscape, and a form of green vegetation. A merging of the classical locus amoenus with vernacular features as it was found by Ananya J. Kabir in Old English literature includes "adjectives of greenness, light or space and a noun denoting an open area of vegetation" (144). In contrast, the locus horribilis ("dreadful place") can be seen as the opposite of Paradise: "a blighted landscape, place of horror, vast solitude, and impassability, abounding in savage beasts and demons" (John Howe 212).

For that reason, heaven and hell as they are depicted in the Bible and especially in Genesis $A$ can be seen as the epitomes of the locus amoenus and the locus horribilis. As both places refer to the soul's eternal destiny after the body's death, they can be regarded as the two main locations of the landscape of the afterlife in the Christian imagination. Their contrasting juxtaposition creates a spectrum of possibilities for a landscape portrayal that conveys both physical features and a Christian morality. Naturally, this notion influences the perception and evaluation of earthly landscapes, as the concrete realities of this world are compared to what one expects of the hereafter. The fact that Gutblac $A$ as well as Guthlac B begins 
with an allusion to Paradise and heaven as an area of the divine creation demonstrates the importance of heavenly and infernal landscapes in both poems.

The Creation narrative marks the first assignment of moral categories to light and darkness in Christian mythology. Only after God creates light and separates day from night can the world be transformed from a vast and void chaos into a habitable living environment. Thus light and darkness are a significant part of the medieval Christian cosmology. Alvin A. Lee finds that the westen of the Guthlac poems is reminiscent of the description of the westen in Genesis A (105). Before God created the earth, there was also nothing but darkness, a vast and deep abyss that was equally empty and useless (Gen.A 103-11).9 This changes when God commands a halig leoht, a "holy light" (124) to appear over the westen as part of his creational process. Although Guthlac does not create the site of his hermitage by himself, he is the one who undertakes the task of turning it into a place that, although it can never reach a state of paradisal perfection, is nonetheless habitable for a pious person. On first sight, the conditions that Guthlac finds on the fens are a striking contrast to the imagination of paradise as the most perfect place. The following analysis will examine whether this is true throughout the narrative and turn its attention to the occasions when Guthlac's surroundings exhibit ambiguous or even positive characteristics.

Guthlac B begins with a rendition of the Christian creation myth and Adam and Eve's dwelling in Paradise. Adam as the first man and forefather of humankind was born in Paradise, which had been created as a leoht ham ("bright home," 834b) for Eve and himself. The depiction of this ideal place is rather abstract, as the poet focusses rather on transcendental categories such as immortality or eternal bliss than on the actual setting: Adam wants for nothing in the idyllic place and neither death nor transience in general can touch him. This shows the link between the locus amoenus and the inexpressibility topos (Unsagbarkeitstopos): instead of giving a detailed account of the delights and joys that await the soul after its passing, the absence of negative attributes such as death, decay, misery, and grief is emphasised:

on neorxnawong pær him nænges wæs
willan onsyn ne welan brosnung
ne lifes lyre ne lices hryre
ne dreamas dryre ne deaðes cyme
ac he on pam lande lifgan moste
ealra leahtra leas, longe neotan
niwra gefeana (Guth.B 827-33a) $)^{10}$

\footnotetext{
9 All quotations and translations from Genesis $A$ are taken from Anlezark.

10 "In Paradise, where he [Adam] had no lack of any desire, nor corruption of happiness, nor loss of life, nor fall of the body, nor decline of pleasures, nor the coming of death, but he was able to live on that land free from all sins, and to make use of the new joys for a long time."
} 
The enumeration of negative attributes, connected by the repeated use of ne, forms an antithesis to the place of perfection and allows the poet to avoid a definite portrayal of the unmentionable; this formula is frequently found in Old English descriptions of Paradise (Steen 43-53; Tristram 104). What is more, the abode allows a perfect unity between the mind and the body, which is presented as a desirable ideal state (827-44). Thus Paradise is established as the true homeland (eðel, 844a) of humanity in which they are allowed to dwell for as long as they will obey their creator. This psychological quality of Paradise had already been established by Augustine, who understood it as a physical as well as a spiritual site: Paradise is not only the place where God places humanity after its creation, but also "every place where the soul is in a state of well-being or grace" (Piehler 79).

After the Fall of Man, which marks the greatest disobedience they could commit, this harmonious home and state of inner peace is taken from them: "Sippan se epel uðgenge wearð / Adame and Euan, eardwica cyst / beorht, oðbroden" (Guth.B. 852a-54a). ${ }^{11}$ As a punishment for their sins, they-and all their children after them-are expelled and forced to live in a "world of toil" (gewinworuld, 857a) in which they have to face death. The separation of the soul from the body is another way in which they have to atone for their immoral act. As a result, they deprive the whole of humanity of the experience of this deore ham ("dear home," 871a). Although Adam and Eve are not exactly homeless, they can still be considered exiles, because they are compelled to live in an environment that lacks many of the pleasures and especially the felicity of Eden. In comparison to their former home, the earth is inferior and flawed.

Both the displacement and the forced existence of the eternal soul in a mortal body are unfortunate conditions that will be amended by salvation. According to Christian belief, the imminent Resurrection of the Dead will apply to the believers' bodies as well as their souls, which means that there will a restoration and subsequent transformation of the transient physical form into a glorified figure (Alexander 9). This outlook is repeatedly emphasised in the accounts of Guthlac's life and spiritual process. The poet of Guthlac B raises the hope of the reader by stating that there are many on earth who are holy in their spirit and who are accordingly living by God's will and performing their work in his name. The abodes of these men can be found in "stedewonga stowum" ("plain and open places," 875) and they supply healing, consolation, and general support for the dwellers of earth who are afflicted by death, illness, or depression (871b-90a). After this prelude, the poet identifies Guthlac as one of those holy men and supplements this with the reference to books that tell of Guthlac's achievements (876a-80a). Nevertheless, even the saint's habitation reflects the imperfect state of the world: troops of devils trespass on his house (894-97). This creates a notable contrast to the aforementioned tranquillity and safety of Paradise. The demons

11 "Afterwards the homeland passed out of Adam and Eve's possession, the bright choicest of dwelling-places was taken away." 
attack Guthlac in various ways and the "wilderness" (westen, 899a) is filled with their presence. This is the first time that Guthlac's surroundings are mentioned in this poem, and the placement in the wilderness alludes to a region that is characterised by the lack of civilisation and cultivation. Likewise, the wilderness and the dark and secret places as they are portrayed in Guthlac $A$ are violated by evil spirits who were able to settle there. Guthlac's arrival marks the end of an era of "spiritual pollution": according to the poet, the dygle stow ("secret place," 215a) that used to stand "empty and desolate" ("idel and æmen," 216a), was waiting for a betra byrde ("better guardian," 217b) to make his claim. The secrecy and mystery surrounding the mountain is also an indicator for its possible connection to the Otherworld or hell (Michelet 183). Early on, this points to the superiority of heaven as a home, especially in comparison to the transient earth, whose wild places are dominated by Satan and his host of fiends. A similar notion is also expressed in Guthlac B when the dying man conveys a feeling of pleasant anticipation for the "sellan gesetu" (1268a), the "better habitation" offered by the "eternal dwellingplace" ("ecne geard," 1267a). Guthlac $A$ introduces not only the concept of the soul's detachment from any "earthly pleasures" ("eorthan wynne," $2 \mathrm{~b}$ ) and "temporary joys" ("laenan dreamas," 3a), but also the idea of death as the ultimate return of the soul to its much-desired true home. This introduction foreshadows Guthlac's death as it describes how the soul of the blessed one is accompanied by angels on its last journey to the halig ham ("holy home," 10a). The paths that lead him to heaven are pleasant and illuminated by a glorious and bright light ("wuldres leoht / torht," 8b-9a). In contrast, the earthly home is merely a stopover that is marked by its deterioration (30-59). The poet emphasises that heaven is-unlike middangeard_an eternal homeland for Christians (“eðel ece bideð," 67).

\section{The House of Hell: Hidden Domains of Darkness and Death}

In contrast, darkness resonates with death, sickness, and the foulness of demons and criminals. Neville finds that the natural world is "explicitly identified with darkness" in Gutblac A (138). Not only humanity's helplessness in the face of the natural world is more prominent at night, darkness also enables secrecy and mystery: the hamas on heolstrum (83a) that some occupy in the wilderness can either be translated as "houses in hidden places" or as "houses in darkness." Both renderings convey a sense of isolation, because they illustrate the houses' concealment from the world. The voluntary exile in these places is evidently only a transitionary dwelling-place, because the inhabitants are yet waiting for the "heavenly dwelling" ("heofuncundan / boldes," 83b-84a). In contrast to the holy home, the belle bus ("house of hell," 677a) to which the demons carry Guthlac in the Guthlac A poem is not only characterised by affliction and destruction but also by sweart sinnehte (678a), the black perpetual night that dominates there.

Guthlac is heavily affected by the absence of light as it increases his vulnerability, thus the demons often choose the night-time to attack and assault the holy 
man (Guth.A 129a and 350a). In Guthlac B, the saint falls ill at night, because his composure is weakened in the nibtglom ("gloom of night," 943a). He himself reports to his servant that the pain began to affect his body "in this dark night" ("in Jisse wonnan niht," 1028b) and predicts his own death on the eighth day after seven nights of suffering (1034b-38a). Nevertheless, he manages to stay faithful and keep his courage despite the darkness ("deormod on degle," 952a), because he has the support of God and his angels. The account of his death is filled with images that symbolise the struggle between darkness and light that takes place not only on an individual level but also on a bigger scale. The separation of body, mind, and soul is of utmost importance in this context. As the poet emphasises, both the bancofan ("bone dwelling," "body," 942b) and the breosthord ("treasure of the breast," "mind," 944a) falter, the soul is keen to move on and enter the paths towards heaven (944b-45a). Later on, the body and mind are depicted as a sinbiwan (968b), a married couple, whose shared life is separated by death (967b-69a). In conversation with his servants, Guthlac points out the parallel between the transitory state of the earth as the dwelling-place of the human race and the body as a transient home for a person's soul. By calling his sawelbus ("soul house," 1030b) a fage flaschoma, a fleshly covering that is doomed to death (1031a), he stresses the mortality of his body, but also the transience of the sickness that has befallen it (1027-33). In the end, both the world and the body are destined to pass, because they are only temporary abodes that will be replaced by the Christian's true home. Thus for the Christian, dying and going to heaven mean the return of his or her soul to the eternal homeland, a union that was disrupted by Adam and Eve's expulsion from Paradise. Guthlac's sickness is even directly related to the deadwege, ("deadly cup," 991a) that Eve took from Satan and prepared for Adam and consequently for all their descendants (976-96). It is due to Eve's wrongdoing that Guthlac is suffering from sickness and death. It is interesting to note that the poet chooses to retell this narrative with a "bitter drinking cup" ("bittor bædeweg," 985a) as the origin of sin instead of picturing a forbidden fruit as the object of offence. Thus they embed Guthlac's personal story of suffering once again into the greater context of the history of salvation that spans the Old Testament as well as the New Testament. It also clarifies Guthlac as Christ's follower, because a cup — or more specifically, a chalice-has an important role in the events surrounding Jesus's death. It is not only used in the Eucharist where it contains the blood of Christ, but it also functions as a symbol of sin and suffering. Jesus prays to God to "let this chalice pass from [him]" (Matt. 26:39), which means that he pleads to be spared from his imminent death on the cross. Even though humankind may not escape the ancient decree (fyrngenyrht, Guth.B 971a) and inherited doom (dom, 972b) of death altogether, it is still only owing to Christ's sacrifice that Guthlac as one of his successors can hope for the preservation of his soul and the deliverance from sin after his passing. 
Furthermore, death is personified as the enge anhoga, the "cruel solitary one" (997a) that approaches the ill man through the shade of night (999a). However, it is only the prelude to Guthlac's death in which death, darkness, and sickness dominate. When it comes to his actual passing, the hopefulness with which he keeps comforting his servant who is distressed by the saint's condition is reflected in the appearance of light. Guthlac's focus on his journey onward to heaven is intensified by the fact that it takes place around Easter; this draws another parallel between Guthlac and Christ's Passion and following resurrection (1098b-104). The poem is deliberately ambiguous in its use of pronouns, so one cannot determine whether it is Jesus or Guthlac who is meant by eadig wer, the "blessed man" (1105a) who rejoices in bliss on the "bright day" ("beorhtan dæe," 1106a) and triumphs in his trial.

\section{The Battle of Light and Darkness: The Biblical Narratives}

On the evening of Guthlac's death-day, the sun sets as always, and the poet describes how the sky turns dark (Guth.B, 1278b-79). Clouds ("wolcnum," 1280a), mist ("miste," 1280b), and darkness ("pystrum," 1281a) contribute to the impression that Guthlac will experience the ultimate night before the salvation of his soul. The following imagery of the juxtaposition of light and darkness is characterised by the extended use of superlatives in the description of the light phenomena that are taking place. The sudden appearance of the leobta mast (1282b), the "greatest light" that shines from heaven, disrupts the previous sombre scene of nightfall. The splendid radiance illuminates Guthlac's house for the whole night and casts out the gloom (1282-92). There is a wide range of synonyms for this light, which stresses its association with God: the poet calls it wuldres scima ("splendour of glory," 1286b), leobta glam ("bright radiance," 1289b), and heofonlic condel ("heavenly lamp," 1290b), which illustrates that the glow is not only a source of light but also an important attribute of heaven. Although one can argue that all these phrases represent the sun, the fact that the scene takes place at night adds a sense of wonder. Therefore, it is reasonable to assume that this multitude of expressions not only denote the sun as a light-giving body but also the concept of a godly and holy light. This imagery becomes even more prominent in the account of Guthlac's soul leaving his body after his passing. The heavenly light turns into a beama beorbtast ("brightest of beams," 1309a) that shines on and around the saint's dwelling-place. It is also compared to a beacen ("beacon," 1309b) that reaches from the earth into the sky like a "flaming tower" ("fyren tor," 1311b). Moreover, the beam is described as surpassing natural phenomena in their grandeur. Firstly, it is raised from the ground to rodera hrof, the "roof of the heavens" (1312b) which is in itself a reflection of Guthlac's extraordinary connection to the realms above the earth; as a saint, he is closer to God and heaven in mind and body. It also illustrates a cosmic architecture in which heaven is stretched above the earth like the roof of a house, and therefore functioning both as a border and as a protection. This image 
already appears in the story of Genesis $A(112-16 \mathrm{a} ; 146 \mathrm{~b}-50)$. Secondly, the beam excels both the brightness of the sun and the beauty of the stars (1313b-14a) which demonstrates its divine quality.

Both heofonlic condel as a metaphor for the sun and the beacon that takes the form of a flaming tower bear some resemblance to a passage in the Old English Exodus narrative. When Moses leads the Israelites through the desert, they are accompanied by two beams that offer guidance and protection by day and night (Exodus 93-97). Especially the ray that appears at night is described in a strikingly similar manner to the one that appears in Guthlac B:

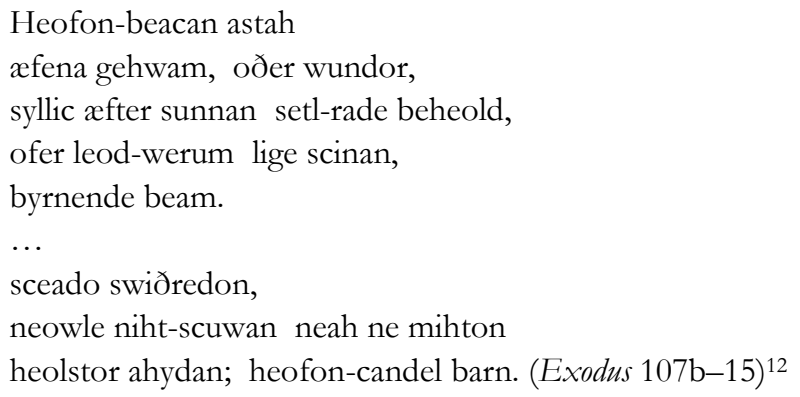

This leads one to believe that God prefers a certain type of landscape in which he chooses to place his people. Both incidents take place in the wilderness, and in both cases God sends divine help in the form of light phenomena. The landscape's desolation influences the way in which the people have to prove themselves worthy, but they also allow a very specific interaction with the divinity. Neither the Israelites nor the English saint are left to their own devices, because they have shown their willingness to face hardships in order to achieve transformation and development. The blazing beam can be read as both a physical and spiritual sign post that keeps the pilgrims safe and on the right track towards the heavenly kingdom. The miraculous appearance and intensity of light serves as a proof that God does not let his believers lead a life in darkness but provides shelter and direction for those who put their trust in him. Thus the journey of Guthlac's soul to heaven is once again connected to another narrative that tells of a journey undertaken by God's chosen people. This reinforces Guthlac's special status and strengthens the objective of his endeavour. It also constitutes one of the perquisites that the Lord grants for the honouring of his name and the search for wisdom. This idea is expressed in a similar fashion at the end of Guthlac A: God rewards the aspirations for wisdom and truth by clearing pleasant paths of life for the souls that are reaching for the light ("sawlum rymeð / lipe lifwegas

\footnotetext{
12 "The heaven-beacon rose up each evening, the second wonder, kept its course happy behind the sun, shining over the people with flame, the burning beam ... The shield covers shone, shadows diminished, the deep night-shades could not hide in the darkness; the heaven-candle burned" (Anlezark 213-15). All quotations and translations from Exodus follow Anlezark's edition.
} 
leohte geræhte," 767b-68). Admittedly, Guthlac's self-imposed exile in the English wilderness may not be the epitome of an easy and pleasant life, but it is nevertheless eased by God's aid, and the prospect of the eternal life in the Lord's kingdom outweighs the misery.

This is hardly the only reference in the Guthlac material to a biblical story concerning lighting conditions. Another look at Genesis $A$ reveals that there is a distinct and well-established theological connection between holy light and devilish darkness. Adam and Eve were not the first ones to experience the deprivation of heavenly light as a punishment for their sins: the traitor Lucifer and the angels who follow him in his arrogance are disciplined by being banned to hell which is described as a "torture chamber of exiles, deep, deprived of joy" (Anlezark 5). They are "bound in unending night, filled with torment, pervaded with fire and intense cold, fumes and red flame" (Gen.A 42-44a). ${ }^{13}$ This depiction of the banishment that the fallen angels have to dwell in after their conspiracy against the Lord is very similar to the hell that is described in Gutblac A. After he successfully overcomes one of their attacks, the demons abduct Guthlac and lead him to the "gate of hell" ("heldore," 559b). They enter that "hideous dwelling-place" ("atule hus," 562b) which is apparently located in an abyss beneath the ground ("niper under næssas neole grundas," 563). The contrast between the heavenly home and the infernal abode could not be made more obvious than in this conversation between the saint and the wicked spirits. The demons threaten Guthlac with his descent into hell and his loss of the light that the Lord has in heaven (582b-84a). Interestingly, the demons are also the ones who give an account of the heavens as heabgetimbru ("lofty buildings," 584b) and who place God on a "seld on swegle" ("seat in the sky," 585a). Likewise, Guthlac B describes heaven as "halig on heahpu" ("holy in the high place," 1088a) and the saint states that he is eager for his soul to take its abode in the afterlife, that is the dwelling on high ("upeard," 1078a). On top of that, the path to heaven that his soul is led on is twice referred to as an upweg, as an "ascent" (1306a, 1366a), which clearly alludes to Christ's ascension and therefore encompasses a spiritual movement upwards. Thus heaven and hell are portrayed as places that are above and beneath the space that humans inhabit. Still, the journey to one or the other is usually triggered by a person's death, which encourages their interpretation as real places that are only accessible to humans as spiritual destinations.

Another incident that exhibits the prevailing spatial concept is one of Guthlac's very first trials when the expelled demons lift him up in the air and give him the power of superhuman vision (412-26). In an attempt to break his steadfast posture, they proceed to show him the moral failures of other ecclesiastical men. Although it can be argued that the monk is at the mercy of the forces that raise him up and does not voluntarily take the position of a seer, it is still telling that he

13 "Syn-nihte beseald, susle geinnod, / geondfolen fyre and fær-cyle, / rece and reade lege." 
is brought into this situation in the first place. His heightened position "on pa hean lyft" ("high in the air," 412a) comes with an increased potential of wisdom and power that can be related to the closer proximity to heaven-hence, the demons recognise the sky as the realm of the Lord which is why they imitate God's position in the cosmos in order to expose Guthlac to the corrupt godlike power that is part of their scheme. Yet again, they remain unsuccessful in their endeavour and they have to lead the man back to his dwelling-place on the ground (427-28). Guthlac's subsequent climbing on the hill then reads as a triumphant ascent (428-30). He is not only able to survive the assault unscathed, but even reinforces his entitlement to the land by walking up the mountain. Especially in a Christian context, mountain tops are frequently portrayed either as the divinities' place of residence or as a site where mortals would receive divine revelation. Wentersdorf gives the pronouncement of the Ten Commandments to Moses on the Mount Sinai as an example. As a further matter, he finds that the concept of Guthlac's exile and conquest of a "high and lonely mountain of faith and virtue" is a widely used symbol for the Christian way of life in general (136). By climbing the hill after the devils let him down again, he brings himself in a similar position as before- that is in physical closeness to the sky and consequently to God-but this time he does it on his own terms and by his own strength. As a result, this whole episode not only recalls the aforementioned experience of Christ in the desert who was also led onto a mountain and given extraordinary vision, it also makes use of the imagery of an ascent as a symbol of spiritual progress and growth. One can argue that the mountain as a geographical landmark is situated between the sky and the ground, which can be interpreted as a symbol of an intermediate state between heaven and hell. This contributes to a certain ambiguity surrounding Guthlac's abode, but it also highlights his spiritual condition, which is clearly influenced by his human existence as well as his standing as a holy warrior. Accordingly, Guthlac's place in the world is situated somewhere between salvation and damnation, which makes his elevated residence a perfect reflection of this status.

Another reading of this scene that has been brought forward by Lee is the interpretation of Guthlac's re-appropriation of the mountain as holy territory as necessary for the "cleansing of his soul" and thus analogous to Christ's Passion (107). The persecution and torment that Guthlac has to endure is analogous to the suffering and hardships that God put on himself when he sent his son Jesus Christ into the world (Guth.A 521-29). With this in mind, Guthlac's afflictions form a significant part of his own salvation history. Similar to the saviour who died in order to redeem humanity's sins, Guthlac becomes a halig cempa ("holy warrior," 513b) and martyr ("martyr," 514a). His faith does not waver and he identifies his abusers as the fallen angels who were condemned to exile, which links his own battle against the devils in England to the very first strife and disturbance of creation: 
Sindon ge wærlogan: swa ge in wræcsiðe

longe lifdon, lege biscencte,

swearte beswicene, swegle benumene,

dreame bidrorene, deaðe bifolene,

firenum bifongne, feores orwenan,

pxt ge blindnesse bote fundon. (Guth.A 623-28) ${ }^{14}$

This shows that hell is simultaneously perceived as a physical and as a spiritual realm. Its physicality is characterised by its location beneath the ground, a dominating darkness, and agonising flames. The darkness that the exiles experience there is both an absence of light and a symbol of the utter hopelessness of the place. The presence of sin, suffering, and death is equally part of the punishment they have to face. Because of their pride ("oferhygdum," 634a), the evil spirits are forced to eternally endure "deað and pystro" ("death and darkness," 635b) in hell, which is specifically designed as their home (677). On top of that, there is no prospect of a possible redemption for them in the future, as they are bound to live in hell forever and cannot expect pardon (635-37). Guthlac uses this condition as a self-defence and as a means to strengthen his own claim of the land. He reminds the devils of their penalty and opposes them by emphasising his own chance of salvation. Unlike the fallen angels, Guthlac can hope for heaven as the betra ham ("better home," 654b), because his heart is filled with the light of belief and the love of God ("leohte geleafan ... lufan dryhtnes," 652). In his faith in God, he is illuminated by light ("leomum inlyhted," 655a) and looks forward to entering the eternal homeland. In contrast to the "fæeger and gefealic" ("beautiful and pleasant," 657a) abode that is heaven, the dreadfulness of hell is illustrated by the "sweart sinnehte, sacu butan ende, / grim gæstcwalu" (678a-79a). Again, the cruel nature of the place affects both the body and the soul: while the black perpetual darkness contributes to an abominable physical landscape, the never-ending contentions and the bitter torment of the soul impact the spiritual well-being of its inhabitants.

However, Guthlac is not alone in this fight. God provides him with spiritual guardians and warriors, namely angels who act as his moral support. The tradition of angels as heavenly messengers whose comings are often marked by light phenomena such as halos or a general illumination can be traced to several biblical passages, but one of the most prominent occurrences is surely in the Gospel of Luke. When the angel visits the shepherds on the fields in order to bring them the message of Christ's birth, it is written in the Gospel of Luke that "Oa stod Dryhtnes engel wið hig, and Godes beorhtnes hym ymbe scan” (Thorpe 117). ${ }^{15}$

\footnotetext{
14 "You are faithless people: accordingly, you have lived long in exile, sunk into flame, darkly deceived, removed from light, deprived of joy, commended to death, surrounded by sins, being without hope of life, that you might find the cure for your blindness."

15 "There stood God's angel with them, and God's brightness shone upon them."
} 
The "brightness of God" that shines upon the shepherds can be interpreted both literally and metaphorically; in a figurative sense, it embodies the message of hope and salvation that the angel delivers to the people. In Guthlac $A$, the connection between light and life is further explored by depicting Jesus Christ as "lifes leohtfruma" ("origin of light and life," 593a). Thus brightness and light can have a divine quality and function as an indicator of holiness. The angel who arrives shortly before Guthlac's passing shines daeghluttre ("brightly as day," 693b); his task is to protect the man's spirit and to put the "servants of darkness" ("peostra pegnas," 696a) into chains. For Guthlac, the angel also functions as a spiritual guardian who leads him in the darkness of this world; assigned to him by God (110b-13), the celestial attendant supports and comforts him. This is also emphasised in Guthlac B: only at the end of his life, Guthlac reveals to the servant who takes care of him that the mysterious person who comes to visit the monk, often between dawn, the dark of night, and in the morning (1216b-21a) is in fact a messenger from God. He explains that ever since his second year in the hermitage the Lord has sent him an angel to comfort and heal him after the nights he spent battling the devils (1238b-48a).

As God's servant and warrior, Guthlac is naturally aware of the earth's transitory state and focusses his spiritual efforts on the afterlife: he rejects his earthly native land and puts his mind towards the home in heaven (96-98a). The angel's protection and assistance is especially useful at night when the monk is visited by evil spirits who try to tempt him. One of them specifically urges Guthlac to seek the company of criminals at night $(127 \mathrm{~b}-28 \mathrm{a})$ and to imitate their corrupt lifestyle. On another occasion, the demons attempt to manipulate him emotionally into surrendering his hermitage and returning to the comfort and safety of human settlement. They come "purh nihta genipu" ("through the darkness of the night," 350a) and appeal to his presumed longing for companionship (350-55). The night is therefore the time when the devils find the monk at his most vulnerable. Apparently it is also the time when they can roam most freely, as God's power is if not diminished then at least less present, especially in the wilderness. However, all their attempts to hurt or to tempt him are in vain, because Guthlac is protected by the angel serving as God's light, even at night. After he has successfully endured another attack of the devils, the "light of the firmament" ("swegles leoht," 486b) is revealed to him. This enhances his grace and distinguishes him even more from the wretched creatures that refuse to obey God and his power.

The above analysis has shown that the lighting conditions give the landscape a spiritual quality. In general, bringing light into the darkness is a complex theme in the Guthlac poems. While it is a significant act in the aforementioned creation of the world, it can also refer to the transformation of the wilderness and spiritual enlightenment in general. This notion is indicated in the prologue of Felix's Vita. He draws a theological connection between darkness, ignorance, and evil: "[W] hen you think you have the light, you be blinded by darkness — that is to say, 
lest when you would refute certainties, you be darkened by the blackness of ignorance ... indeed, the origin of all evil springs from ignorance" (Colgrave 63).

In the Vita, this theme of illuminating blindness and ignorance forms a frame. When Guthlac is dying, the house is filled with a "heavenly light" and a "tower as of fire" (Colgrave 159) and one of the miracles that is performed by means of his relics is the healing of a blind man through salt that was previously consecrated by Guthlac (167-71). This is certainly a reference to Christ's miracles of healing as they are described in the New Testament; it is also further proof of Guthlac's holiness, because his body and the objects attributed to him perform miracles after his death.

Tracing Visions of Paradise: The Garden and the Hall

One of the most prominent features of medieval landscape symbolism is the polarity of city and wilderness (Piehler 72). According to Paul Piehler, the human experience of the environment adds to an underlying psychological concept that manifests itself in the fundamental conflict between man and wilderness as it was adapted by writers in the Middle Ages from ancient literature (72-75). While society and accordingly the city represent a state of "rational consciousness," the settings outside of the city are "symbols of the vast powers of the imagination" as well as "the very place of their operation" (73). Based on this notion, a hero can be defined as a person who is able to acquire the rational perception of their community and perform it while living in the wilderness, to "bear into the wildness a city within himself" (74-75).

Likewise, the dichotomy of the paradisal wilderness and the heavenly city or the hall in Old English poetry is a recurring theme in the literary discussion of landscape and its religious symbolism (Kabir 4-5; 7-8). The stylistic devices and stock images in the description of Paradise that Tristram locates in Guthlac B are part of several formulae she identifies in Anglo-Saxon poetry which are used either for the visual or the metaphysical portrayal of landscape. Since the ones she finds in the Guthlac poem are usually used to depict heaven, she argues that "heaven is often confused with paradise" (106) in Old English literature. Kabir relates the equivocality surrounding Paradise and heaven to the prevailing semantic fluidity as well as the coexistence of various imaginations of the afterlife in early Christianity (3). A continuous transition between the two predominating representations of life after death can be found especially in Gutblac A. Paradise is pictured as the Garden of Eden that is the epitome of natural beauty, while heaven is imagined as a delightful hall filled with companions and riches (Kabir 142). Thus the Christian landscape contains visualisations of idealised spaces of contrasting features, most importantly inside and cultural (the hall) versus outside and cultivated nature (the paradisal garden). Although one should refrain from applying these concepts without questioning and challenging them, they can still be useful points of reference and provide a categorical framework. 
Lee points out the mythical, paradisal connotations surrounding the portrayal of the landscape in the poem, which can be seen especially in Guthlac's last return to the beorg after the intervention of Saint Bartholomew (107-08); he argues that the imagery in the passage resembles the "revival of the life of Paradise, especially as [it] is depicted in the lives of the desert fathers" (108). Serving as Guthlac's habitat enables the site to realise its full potential: after his return to the hill, Guthlac finds it to be a sigewong ("place of victory," 742a) and a sele nime ("new hall," 742b). As the saint has been established as a warrior and soldier of God throughout the poem (91a, 153a, 180b, 324b, 402a), the reference to a hall in this context equates his homecoming to the entry into Paradise. The hall is not only a location of celebration after a victorious and glorious battle, it is also part of the pagan concept of Heaven. As it is, the identification of the hill as a "new hall" may be another faint pagan echo; for instance, Valhalla as it is described in several Old Norse texts is a location where kings, soldiers who have died in combat, and heroes feast and drink side by side with the Gods (Patch 60-66). Even without this mythical connotation, the hall is an architectural structure that is erected by humans as both a meeting place and a shelter. In an ideal case, it provides a safe space and keeps out dangers of the natural world, be it harsh weather or monsters. Architectural imagery is often used to represent the magnificence and delightfulness of heaven (Kabir 147-50). Hence the hall has an appeal that affects the human being emotionally, visually, and architecturally.

The hall in Old English poetry is a prominent image representing the community and its values that influences the landscape both literally and metaphorically (Magennis 35-40). It is noteworthy that the Guthlac B poet also makes use of the image of the hall, but in a distorted sense: in the poem, hell is considered to be a deadsele ("hall of death," 1075a), which is characterised by pain, sorrow, deprivation, exile, shame, cruelty, and hopelessness (1072b-76a). This reinforces its contrast with the pleasant and idyllic hall that Guthlac finds on his return, and sets him even further apart from the devils. This is especially fitting if one looks at the way Guthlac fights his sickness in Gutblac B: while it is the ongoing battles for the land that make him a soldier of God in the first place, his final struggle is against a disease. Despite the use of battle imagery such as "war-shower" ("hildescurum," 1143b), "flickering force of arrows" ("flacor flanpracu," 1144a), "stricken by deadly darts" ("awrecen wælpilum," 1154a) and "fatal arrows" ("wælstrælum," 1286a), it is nevertheless expressed that his true victory is based on his endurance and acceptance of death, not on brave and tireless fighting. Guthlac becomes an exemplary being due to his unfailing piety and faith in God that causes him to not be afraid of leaving the earth but to look forward to entering the realm of heaven instead.

For Guthlac, the return to his hill marks the completion of his duty as God's servant, because the transformed hermitage symbolises his purified soul and the triumph of his unfailing faith. According to Lee, bringing the location under the 
protection of God (746) and depriving the demons of all authority over it marks the "realisation of Paradise" for Guthlac (108). Guthlac B also features an episode that sees the blossoming and reawakening of the natural world. The poet compares the sweet smell that comes from Guthlac's mouth to a fertile and delightful summer scene with blooming flowers filled with honey (1273b-78a). The fact that his departure from earth is accompanied by such a life-affirming scene shows that the saint's death is not the end of all things but rather the transition into a promising and spirited existence. This odour of sanctity is a recurring theme in Catholic liturgy and one of the ways in which the incorruptibility of the saint's body is foreshadowed. It is revisited at the very end of the poem: combined with the holy songs sung by the angels, the fragrant odour adds to the sensual experience of Guthlac's death as it is perceived by himself and the present living beings (1322b-25a).

Furthermore, this scene demonstrates that it is not only Guthlac's presence in the wilderness that affects the landscape; in addition to the miraculous visual and olfactory phenomena that mark the onward journey of his soul, the land reacts rather violently to the death of his body with an earthquake: "Beofode prt ealond, / foldwong onsprong" ("That island trembled, the earthly plain burst forth," 1324b-26a). At first sight, this sudden and disruptive movement of the ground is a paradoxical contrast to the peaceful and idyllic scene that has been evoked before, as the potentially great destruction of an earthquake appears to be incompatible with the restoration of Eden on earth. However, earthquakes serve several purposes in the Bible: they can signal the coming of Christ or represent a punishment for committed sins, for instance. The occurrence of seismic activity as a corollary of Guthlac's death is another reference that connects his life with Christ's. Immediately after Jesus's death on the cross, a strong earthquake occurs that damages the temple and destroys the rocks. It also prompts the resurrection of a number of holy individuals from their graves (Matt. 27:51-54). Likewise, an earthquake happens when it is discovered that the tomb is empty because Jesus has risen (Matt. 28:2). Following the crucifixion and resurrection of Christ, the earth's tremor proves to both believers and sceptics that Jesus is indeed the Son of God. It also calls attention to his sacrifice and the huge impact that his actions have, especially on the salvation of humanity. Hence, the saint whose death is accompanied by the same natural disaster is once again ranked among the group of saints who aspire to follow the saviour in their actions and achievements. In this context, his accomplishments as a hermit in the wilderness are his contribution to the history of salvation and analogous to Christ's sacrifice for humankind. Thus the earthquake in Guthlac B is not only a symbol of destruction, but another indication of the forthcoming resurrection of the holy man's soul and his entry into heaven.

The aforementioned sele niwe carries the notion of a renewed dwelling for Guthlac, which corresponds to the Christian understanding of Paradise as the betra 
ham, the better home for the soul after the end of one's earthly existence. Other words and phrases that indicate the hill's transformation into a greater, more paradisal place include smolt ("pleasant," 742a), "wæs ... folde geblowen" ("the earth was in bloom," 743b), and grene wong ("green place," 746a). The green place is another example of the use of formulaic phrases in order to describe Paradise as a place of natural perfection. In Old English poetry, the adjective green is regularly associated with the landscape of Paradise; thus algrene ("all green") is the favoured adjective for the land of Canaan in Genesis $A$ (Alexander 15). This formula is apparently inherited from Germanic tradition as it is paralleled in Old Norse and Old Saxon literature (Magennis 147-48). Especially the collocation of grene and wang also appears in the idealised landscape descriptions in Old Norse and Old Saxon texts (Kabir 144; 146), for example in the Heliand (Behaghel and Taeger): "grôneo uuang" (757), "grôni godes uuang" (3082), and "grôni uuang" (3135; 4285).

However, it is necessary to note that the place Guthlac selects for his hermitage is described in surprisingly pleasant terms even before the fulfilment of his quest. In Guthlac A, the mountain is located in a grove ("on bearwe," 148a), which is one of the stock images of the locus amoenus and also designates a certain greenness. Thanks to the angel's comfort and support, his experience as a hermit is not solely characterised by terrors and demonic assaults, but also by a pleasurable and delightful landscape:

sippa[n] frofre gæst

in Guðlaces geoce gewunade,

lufade him and lærde, lenge hu geornor,

pæt him leofedan londes wynne,

bold on beorhge. $(136 \mathrm{~b}-40 \mathrm{a})^{16}$

As Fabienne Michelet points out, the happiness that the man gains from his remote dwelling-place does not come easily to him; it is rather the combination of the agreeable landscape and the angel's spiritual support that contribute to Guthlac's ability to appreciate his surroundings (172-73). His perception of the landscape undergoes some significant changes in this poem: in the beginning the site that God reveals to him as the place of his retreat is solely a means to the end of spiritual completion. Even so, the mountain grows dear to him and the delight he finds in the natural world is the only pleasure he allows himself after his selfimposed withdrawal from the world of human desires and gratifications. In his engagement with the physical world around him, he also mirrors and imitates God's attitude and emotions towards the world, no matter how flawed it appears: the Lord unconditionally loves and cherishes every creature of his creation (Guth.A 760-62).

16 "From then on, the spirit of comfort remained in Guthlac's aid, he treated him with kindness and taught him ever more gladly, so that the joys of the land, the building on the mound, delighted him." 
Needless to say, the scenery's appeal increases after the conclusion of Guthlac's battle with the demons. As described before, the transformed residence exhibits qualities that make it a paradise-like place - at least as much as this is possible for an earthly location. This shows that Paradise serves as an "archetype of the good landscape" (Magennis 145), which means that Anglo-Saxon poets revert to characteristics such as abundance of greenness in order to mark their portrayed landscapes and natural places on earth as paradisal and therefore attractive and desirable (151). The banished demons also recognise of the place's universal beauty and lament its loss:

hleahtor alegdon,

sorge seofedon pa hi swiðra oferstag

weard on wonge; sceoldon wræcmæcgas

ofgiefan gnornende grene beorgas. $(229 \mathrm{~b}-32)^{17}$

Once again, the adjective "green" is used in order to demonstrate that the place is attractive to both the demons and Guthlac (Magennis 185). Lee connects their wailing and the envy that the demons feel towards the monk-who is an unwelcome trespasser from their perspective-to Lucifer and Cain who are also banished from "the green places they desire" and who then "wait as joyless exiles for future opportunities of attack on the idealized place inhabited by God's servant" (105). The former inhabitants are clearly offended at what is according to them an intrusion into their territory; the fact that the intruder is even supported by the same deity who sent them to exile in the first place even intensifies their bitter emotions which then result in their antagonistic actions.

The recovery and regeneration of the flora and fauna that can be found in Gutblac $A$ represent the powerful oxymoron of the blooming desert. The alteration of his dwelling-place is therefore another step in the preparation of his journey towards the "Father's homeland" ("fæeder eðle," 801), which is Jerusalem, the holy and eternal city (812-18). Magennis considers this another poetic paradox: "in turning his back on earthly communities he [Guthlac] aspires to share in the community of the heavenly city" (187). But the vision of Guthlac joining the other saints and angels as the "cempan gecorene Criste leofe" ("the chosen warriors dear to Christ," 797) in the everlasting kingdom is not only in contrast to the loneliness and his voluntary separation from human company that he experiences on earth. It also conveys the patristic idea of a heavenly city as it can be found in Augustine of Hippo's De civitate Dei (Siewers 36).

In general, Anglo-Saxon religious poetry imagines cities as strongholds that represent society as a whole as well as success and achievement (Magennis 156). In this discussion it is also important to consider what has been pointed out by Nicholas Howe: unlike many modern Western authors, the Anglo-Saxons "did

17 "They gave up laughter, they lamented their grief when the stronger guardian defeated them on the field; the mourning wretches had to give up the green hills." 
not cultivate a moralizing binary between the innocence of landscape and the corruption of civilization." Their imagination of landscapes was rather affected by the "binary between the transience of this loaned, earthly life and the permanence of the heavenly home" (92), which means that the building of a city would not have been interpreted as the intrusion or even destruction of sacred natural spaces.

What makes the imagination of heaven as a city especially appealing is surely the prospect of security as well as the splendour that a community under the regiment of God promises (Magennis 40-41). This tradition of thought makes the transformation of the desert into a city such a compelling image, because city and desert are usually seen as topographical and demographical opposites (Rapp 99). Guthlac B also picks up this theme: in his last conversation with his servant, Guthlac asks him to bring a message to his sister whom he has refused to see in his earthly life so that their reunion in the afterlife could be free from sin (1178b-89a). He then explains that he expects to see her again in the beorbt burb (1191a), the "bright city" that is Jerusalem, where they will dwell among the angels and enjoy the heavenly bliss. One of the first indications of the arrival of the Holy City is surely the warm weather-sign (1293a) that comes from the East, which is the direction that is traditionally associated with Jerusalem and Paradise (Michelet 17). However, Magennis observes a coalescence of the images of a city and the image of a hall in Old English poetry, which means that the classical idea of heaven as a city is merged with the Germanic notion of heaven as a hall (42). That this can observed in the Guthlac poems has been demonstrated by the preceding analysis: the transformation of the saint's dwelling-place into a site with an increased divine quality is described in terms that provokes associations with both the paradisal Garden and the heavenly hall and city, respectively.

The Inner Retreat and Animal Companionship in the Wilderness

Despite his original intention to find solitude in the wilderness, Guthlac finds the landscape to be by no means empty. Aside from demons and angels, it is also populated by wildlife, which is not-in contrast to God's and Satan's delegatesassigned a distinct and constant morality. The animals' moral status is ambiguous, because they do not form a homogeneous group in the Guthlac material. In any case, as they are the only living creatures apart from the saint, the interaction with the animals is an integral part of his living conditions in the English desert. The Gutblac $A$ poet describes how the hermit is welcomed by an amiable wildlife (733-42) that behaves very friendly and tame towards him, because he feeds it (736-38). Moreover, it is explained that he turns to the birds as a replacement for the lack of a human community in his exile: 
Swa pæt milde mod wið monncynnes

dreamum gedælde, dryhtne peowde,

genom him to wildeorum wynne sippan he pas woruld forhodge. (739-41) ${ }^{18}$

Accordingly, in his triumphant return to the new hall, he is not greeted by the songs of men but by the wild creatures' "earnest voices" ("meaglum reordum," 734b) and "beautiful bird song" ("færger fugla reord," 743a). Guthlac's loneliness and separation from any civilised settlement is one of his presumed weaknesses that the devils address; naturally, they also attempt to use it to their own advantage in their battle against his conquest. They try to disturb him by visualising the possibility of starvation in the wilderness (273-88) and hope that he would start longing for his home and "human love" ("monlufan," 353b). However, none of these hopes are fulfilled, as Guthlac neither starves nor becomes depressed by the prevailing lack of human society. The end of Gutblac $A$ shows that he even finds an adequate prophylactic cure for solitude in the region's wildlife. Still, the birds are not anthropomorphised in the sense that Guthlac uses them as actual substitutes for human interaction, but they provide a distraction and an opportunity for him to redirect the need to communicate. With his delight in feeding them and listening to their songs as a reward, Guthlac himself becomes a nurturing father who enjoys taking care of the lives that are put in his trust. It also shows his appreciation of the natural world and in a broader sense God's creation.

Gutblac B, on the other hand, has a different approach to dealing with the assumed loneliness of a hermit, because it focusses on the communal monastic disciplines that Guthlac retains in the wilderness, such as giving counsel. The poem mentions several guests that pay Guthlac a visit on his sigewong and who are healed and comforted by him (919b-32a). He has the company of one faithful servant in his dying moments who is distressed by his condition and mourns his passing (1197-200; 1293-95). Thus withdrawal and separation from the world need not evoke a feeling of loneliness in a person. In Guthlac's case it is apparently no concern of the monk; on the contrary, he is even able to give consolation and advice to the people who come to him. One can even trace a seemingly paradoxical movement in the Guthlac poems: his withdrawal and the isolation from worldliness and worldly communities enable him to alter his spiritual position. Guthlac's life as a hermit forms a passage to the kingdom of God, where he finds an environment in which he can accomplish spiritual completion (Clarke, Writing Power 20). Even though he decides to retreat from his kin and companions, he is still part of the community of God's followers. Guthlac finds a "place of spiritual fellowship" (24) in his solitude and he partakes both as a patron and as a protégé. This also explains his invulnerability and immunity to the devils' attacks: despite

18 "Thus the gentle soul parted with the pleasures of mankind, served the Lord, and took his delight in wild beasts after he turned his back on the world." 
his external withdrawal, he continues to engage with God's spiritual community that grants him protection and support (23-25).

The significance of birds in the context of a saint's becoming is even more apparent by taking a look at Felix's Vita and the Anglo-Saxon Life. In both texts, Guthlac's interaction with birds is given more attention than in Guthlac $A$ and it is also more nuanced. The prose texts are more specific about the different species: Felix mentions a thievish jackdaw (Colgrave 116-19; 124-27), which becomes a raven in the Old English version (Gonser 140; 143-45). Although these encounters with birds may not suit the peaceful image that is drawn in Gutblac $A$, they still contribute to Guthlac's characterisation as a saint, because they illustrate his benevolence, patience, and trust in God. In general, the nearby animals do not function as mere substitutes for human companionship, but they represent further proof of his holiness. Guthlac himself explains the phenomenon of the animals coming to him without any fear or restraint in the Old English prose version. Wilfrið, one of his visitors, asks him "forwhon pa wildan fuglas pæs widgillan westenes swa eadmodlice him on sæton" (Gonser 143) ${ }^{19}$ when he sees two swallows flying into Guthlac's house. The two birds proceed to sit on the monk's shoulders and sing for the man (142). Guthlac tells his guest that it is already written in the Bible that wild beasts are able to recognise a prudent servant of God and consequently approach him. Likewise, the angels come nearer to him because of his voluntary isolation and withdrawal from worldly people (143). In fact, this situation shows a remarkable resemblance to Jesus's temptation in the desert: according to Mark the Evangelist, Christ "was in the desert forty days and forty nights, and was tempted by Satan; and he was with beasts, and the angels ministered to him" (Mark 1:13). Thus one can interpret animals and angels as markers of the holy man in the wilderness. Additionally, Jesus often uses animals in his parables, and encourages people to identity with them. For instance, in the parable of the mustard seed, the birds specifically serve as a metaphor for those who make the kingdom of God their home (Matt. 13:31-32). On another occasion, Jesus uses the carefree birds that do not worry about their nourishment as a metaphor for the care and aid that Gods accords the people who trust in him (Matt. 6:26).

The submission of the wildlife and the companionship of animals is another hagiographical trope that "contrasted the disobedience of men with the compliance of animals to God and his saints" (Alexander 43). This theme is mostly explored in the prose texts about Guthlac: "and næles pæt an pæt him pa fugelas underpeodde wæron, ac eac swa pa fixas and wilde deor pæs westenes ealle hi him hyrdon, and he hym dæghwamlice andlyfene sealde of his agenre handa, swa heora gecynde wæs" (Gonser 142). ${ }^{20}$

\footnotetext{
19 "Why the wild birds from the vast wilderness were sitting on him so submissively."

20 "And by no means was it just the birds that were subject to him, but also the fish and wild animals of the wilderness all obeyed him, and he gave them food from his own hands every day, each according to their kind."
} 
In the Vita, this account is even more extended and besides the animals, nature itself submits to the saint:

For the grace of his excellent charity abounded all creatures, so that even the birds of the untamed wilderness and the wandering fishes of the muddy marshes would come flying or swimming swiftly to his call as if to a shepherd; and they were even accustomed to take from his hand such food as the nature of each demanded. Not only indeed did the creatures of the earth and sky obey his commands, but also even the very water and the air obeyed the true servant of the true God (Colgrave 121).

In contrast to the Old English material, the Latin source gives a justification for nature's obedience. According to Felix, this submission is the restoration of the natural order, because the world was created in subjection to Adam's species. While the creation gladly serves any faithful servant of God, humanity as a whole has lost its supremacy due to its disobedience of the Creator. Interestingly, all of the mentioned living beings (birds, fish, wild animals) also appear in the biblical accounts of the prophet Job. According to Alfred K. Siewers, Gregory's commentary on the Book of Job in his Dialogues was an authoritative text that also influenced Anglo-Saxon literature; thus it is reasonable to assume that Guthlac's hagiography was informed by Gregory's ideas, especially by his allegorising approach to landscape (Siewers 19-20). When Job is confronted by heretics who doubt the creation of God, he answers them: "But ask now the beasts, and they shall teach thee: and the birds of the air, and they shall tell thee. Speak to the earth, and it shall answer thee: and the fishes of the sea shall tell. Who is ignorant that the hand of the Lord hath made all these things?" (Job 12:7-10). This section pictures animals as creatures that, unlike unworthy and arrogant men, are aware of their place within creation and thus have the wisdom of teachers. Likewise, the animals in Guthlac's realm are able to sense his worthiness as God's retainer and act accordingly. In addition, the relationship between the saint and the creatures he feeds is portrayed as amicable and affectionate, which further contributes to the overarching pastoral theme as it can be found in the poem's portrayal of Guthlac's dwelling-place. The friendly relations between the hermit and the animals in the wilderness recall the Garden of Eden, where mankind and animals live peacefully side by side (Alexander 44-46). Furthermore, the birds in Guthlac $A$ are part of a greater theme of renewal and rebirth, which extends the paradisal connotation of his return to the beorg and also foreshadows the resurrection of Guthlac's soul. Especially the sound of the cuckoo is highlighted (744), because it functions as a "metonym or emblem for springtime." 21 Hence the birds are an essential part of the imagery with which Guthlac's mountain is portrayed as an Eden restored.

21 This is interesting, because the cuckoo does not usually connote the hopefulness and revival of spring (Clarke, Literary Landscapes 52). In other Old English poems, such as The Seafarer, this bird is associated with melancholy, forthcoming sorrow, and the general impermanence of all things. Clarke 
However, the saint's interaction with the fauna is by no means exclusively pleasant. This becomes apparent in Gutblac B, which gives a remarkably similar account of the bird-feeding scene. Nonetheless, the family of birds (917a) is strongly contrasted to the devils who take the form of wild deor ("wild beasts," 907b). The birds come "afflicted by hunger" ("hungre preatad," 916b) to be fed by the saint and then express their gratitude by worshipping him with meagle stefna ("earnest voices," 919a). Especially the sound of those earnest voices—a phrasing that is indeed very close to the meagle reorda in Guthlac $A$-is an antithesis of the shrieking devils that imitate wild creatures in their forms and noises (905-12). While the first poem does not specify the demons' appearances, Guthlac B gives an account that combines visual and auditory impressions from the natural world such as the simple "human form" ("mennisc hiw," 909b) as well as supernatural elements like dragons ("wyrmes bleo / earme adloman, attre spiowdon," 911b-12). Demons that take the forms of animals as a disguise frequently appear in texts that deal with Christian asceticism-for instance, in Athanasius's Vita Antonii, which served as a major inspiration of Felix's Vita, Anthony is attacked by demons who almost exclusively imitate animals that are considered unclean for eating in the Bible (Spittler 46). Anthony also makes peace with the wild animals, but unlike Guthlac he neither tames nor befriends them, because their textual portrayal is influenced by a patristic tradition that offers a rather negative conception of animals as symbols of sin and immorality (46-49). The selection of wild beasts that the monk has to face in the wilderness once again shows the close connection between the Vita Antonii and Guthlac's Life. Anthony is assaulted by demons who take the form of lions, bears, leopards, bulls, serpents, asps, scorpions, and wolves (Vit.Ant. 9, Meyer 28). Guthlac's assault by evil spirits' posing as animals is featured in the sixteenth chapter of Felix's Vita. Felix describes how the demons appear as lions, bulls, bears, serpents, boars, wolves, horses, stags, oxen, and ravens and attempt to frighten the saint with their visual appearance and the terrifying noises they make (Colgrave 115). In a similar manner, the Anglo-Saxon Life depicts this episode of a demonic attacks as follows:

Đæt gelamp sumere nihte, pa se halga wer Guðlac his gebedum befeal, pa gehyrde he grymetunga hrypera and mislicra wildeora. Næs pa nan hwil to pam, pæt he geseah ealra wihta and wildeora and wurma hiw incuman to him. Æerest he geseah leon ansyne, and he mid his blodigum tuxum to him beotode; swycle eac fearres gelicnysse, and beran ansyne, ponne hi gebolgene beoð; swylce eac næddrena hiw,

relates these differing connotations to variations between insular, Celtic, and continental Latin traditions that influenced the poet in his interpretation. See Seafarer lines 53-55a and the note to these lines in Klinck (text on pp. 79-83; note on p. 137). 
and swynes grymetunge, and wulfa gepeot, and hræfena cræcetunge, and misclice fugela hwistlunge, pæt hi woldon mid heora hiwunge pæs halgan weres mod awendan (Gonser 139). ${ }^{22}$

The interrelation of visual impressions and aural effects can be found in all three prose texts as well as Guthlac B and it creates an atmosphere of fear and terror that the saint experiences at night. The portrayal of the demons as dugupa byscyrede ("deprived of salvation," 895b) as well as raising animalistic cries (898b-99) serves to illustrate that the dangers that Guthlac has to face in the wilderness are both concrete and spiritual, because it depicts the demons as creatures that are corrupted on both levels.

This corresponds to the general portrayal of animals in hagiographical writing: they appear both as illusions created by the devil and as real beasts (Alexander 20). Hence they function as symbols and manifestations of the threat that the natural world poses to the physical and psychological well-being of its human inhabitants. This literary tradition originated in ancient literature and not only can it be found in the accounts about the Egyptian desert fathers, it also influences the poet's imagined landscape as it is portrayed in the Guthlac poems. For Piehler, the unpredictable shapes of the animals can be identified as either real physical threats or as representations of nightmares and imaginative terrors, which is why they present the primary danger to the rational being in the wilderness (Piehler 73). This notion is based on Prudentius's Psychomachia in which personified virtues and vices fight against each other in order to gain dominance and authority to rule over the soul of man. In this allegory, an army of virtues such as Faith, Chastity, and Patience withstands the attacks of vices such as Lust, Idolatry, and Pride. The combat is described in a naturalistic way resembling the demonic attacks in the Guthlac poems but using military terms to illustrate the spiritual conflict. Thus the allegory represents the moral struggle within the postlapsarian Christian mind (Smith 109-13).

For Guthlac and his diabolical encounters in the wilderness, this raises the question whether the saint experiences real attacks from physical life forms or whether they are projections of his mind that reflect his disturbed inner mental state. In any case, the demons both represent and reinforce the Christian struggle as it is portrayed in the Guthlac material: as unholy outcasts, they have failed the fundamental Christian trial of choosing between worldly desires and the wish to overcome them. Consequently, they tempt the holy man with these human crav-

\footnotetext{
22 "It happened one night, when the holy man Guthlac was saying his prayers, that he heard the roaring of cattle and various wild beasts. It was not long then before he saw the shape of all the creatures and wild beasts and serpents coming to him. First he saw the appearance of a lion, and it threatened him with its bloody teeth; similarly, the likeness of a bull, and the appearance of a bear, when they are angry; likewise also the shape of serpents, and the roaring of boars, and the howling of wolves, and the croaking of ravens, and the chirpings of various birds, because they wanted to agitate the mind of the holy man with their forms."
} 
ings in order to keep him from serving God with a pure heart and to the best of his abilities. In any case, the monk has to prepare himself to fight against evil spirits that embody the threat that the natural world poses to humanity as well as the danger to the soul that emanates from the world and its temptations.

In addition, this passage demonstrates one of the ways in which Guthlac's biography is inspired by other hagiographical writings as well as the process of the cultural adaptation of a known text to a new audience. Both Anthony and Guthlac as they are portrayed in these texts are confronted by devils in the form of lions, bears, bulls, serpents, and wolves. Although Felix keeps the lion and serpents as animals that must have appeared foreign and exotic to Anglo-Saxon audiences, he omits the leopards, asps, and scorpions and replaces them with a few species that are native to England, such as boars, horses, stags, oxen, and ravens. In turn, the Old English translation keeps the boars and ravens, but excludes the horses, stags, and oxen. The fact that the Old English version of the saint's life puts wolves and ravens in sequence inevitably creates an association with the beasts of battle motif, which further reinforces Guthlac's standing as a religious warrior and hero.

\section{The Spiritual Conversion of a Landscape: Guthlac as a Coloniser}

In addition to the question concerning the inherent and expressed moral value of the landscape, the dispute over territory is especially interesting from an ecocritical point of view. It raises questions concerning the issue of legitimate ownership: who owns the landscape? Should it even be considered property or is it rather an autonomous entity that cannot be owned? The answers given by the Guthlac poets in their verses are unmistakably influenced by Christian theology, which has at its core the notion that the natural world is first and foremost God's creation; therefore, it is subject to his will and command. Accordingly, the justification of Guthlac's conquest is intrinsically tied to his status as a holy man and hence his connection to the Lord. The notion that a creature's immanent status can either be divine or demonic and determines a person's position in the world is reinforced when Saint Bartholomew comes down from heaven in order to rescue Guthlac from the hands of his enemies. The concept of a hierarchy among the living creatures in terms of their spiritual rank is already outlined at the beginning of Guthlac $A$ when the poet assigns the speaking angel an older rank or degree ("yldran had," $4 \mathrm{~b}$ ) that indicates his state of being superior to humans in authority and power. Saint Bartholomew is also the only holy messenger who can be identified by his name. His unique relationship to the hermit and the place in which he settles is further explained in Felix's Vita: Guthlac begins to settle in the fens on 25 August, which is the day on which the feast of Saint Bartholomew is celebrated (ch. 27: Colgrave 90-91). Therefore, it appears that the monk's undertaking is under the protection of this particular saint from the very beginning. However, Bartholomew is not only depicted as a spiritual guardian but also as an executor of God's will: he constrains the demons and forces them to not only leave Guthlac be, but to serve him 
as underlings (692b-97; 703-21). The saint states, "he sceal py wonge wealdan, ne magon ge him pa wic forstondan" (702). ${ }^{23}$ With this declaration, Guthlac's power and right to occupy the place is confirmed by a religious authority. Bartholomew also declares that the holy man is the only one who is allowed to live there; this right of abode obviously also includes the right to expel its former, now illegitimate occupants. Hence, one can assert that Guthlac's rank as a holy man is verified and strengthened by the saint's support.

Although both the monk and the demons share their desire to inhabit the same landscape, this motivation is an expression of the crucial difference between them. The evil spirits seek out the fens and wilderness as a refuge that allows them to exist outside of the realm governed by God. It is therefore a reflection of their demonic condition, and they appreciate it because of the suitable living conditions. This becomes obvious in the lamentation of their loss, which is portrayed in a surprisingly sympathetic way: the devils experience great anxiety and sorrow over their homelessness (Guth.A 215-25) which causes them to raise up their voices with grief after they are driven from the green hills (229). They even long for the Lord to put them out of their misery (224-25) - a wish that will never be granted, as one learns from Guthlac's explanations about their nature. Guthlac, on the other hand, wants to dwell in the lands both despite and because of their desolation. To him, the location of his hermitage is not exclusively dreadful, as it already has pleasurable traits like grene beorgas before he converts it into a sanctified place. Still, he arrives with the quest of transforming the region into something that is more agreeable to God while simultaneously proving his own piety. Accordingly, the landscape provides him with the conflict situation that is required for his task and challenges him both physically and spiritually.

As a result, one can say that the Guthlac poems convey a concept of natural abodes that sees hermits and monks dwelling in paradisal sites while demons reside in hellish places. The fact that the same place has the potential to be both or to change from one to the other shows that it is essential to examine the landscape, Guthlac, and the demons as elements of a triangulated network. This angle of analysis allows to observe these three nodes as entities that influence each other in various ways. One of the most pressing matters in this regard is surely the question of the relation between inside and outside, both of the natural world in general and the individual person who inhabits it. According to Neville, the basic state of the environment is amoral: "the natural world is not assigned any inherent moral status" (26). If this is true, one can assume that the portrayal of a morally charged landscape-and the description of a physical scenery that resembles connotations with the religious landscapes of heaven and hell without a doubt adds a certain moral value to the depicted setting - is solely based on the perceived interaction and mediation that takes place between a conscious being and nature.

23 "He must rule that land, you are not able to withhold this dwelling-place from him." 
This is compatible with Neville's statement that "the natural world in Old English poetry does not have an independent identity or meaning ... its meaning is determined by its role, and its role is always a supporting, even a minor, one" (137). Hence, the natural world does not have an intrinsic moral value, but it can only be ever judged by its interaction with the creatures that inhabit it, be they divine, human, or demonic.

Moreover, Guthlac expresses a sense of belonging as well as the notion of a natural order with this argument. The moral value of a landscape and its inhabitants therefore becomes an ideological question of territory, ethnicity, and inheritance. Although it may not be a palpable reality at this point, as he is living as an exile on a transient earth and even forced to reside in hell for some time, Guthlac sees a clear distinction between the destined dwelling-place of the devils and his own, at least on a spiritual level. He reasons that hell is the traditional place for creatures like the wretches that used to inhabit the fens before his arrival; he bases this on the idea that the devils abide in hell as an atonement for their disobedience. Similar to the original sin that Adam and Eve passed on to their offspring and which results in their withdrawal from Paradise, the fallen angels are expelled from their homeland and sent to a place that is not only foreign but also hostile. These circumstances explain their distress about the disturbance of their chosen earthly dwelling-place and the sorrow about its loss due to Guthlac's settlement. In both narratives the devils are actual creatures of the natural setting; apparently, they are also either capable of leaving hell in order to torment people on earth or they have been assigned grim and barren sites outside of the infernal regions as their habitat. Thus Guthlac's interaction with them and his description of the land as home of wretched spirits reveals a world-view that reflects an underlying concept of the natural world that does not exclude supernatural elements such as demons or monsters. Jennifer Neville explains the presence of these devils with the tradition that the fallen angels were not all banned in hell but that some of them were assigned residencies in the sky, water, and woods (105). In general, wild and desolate places are often seen as the natural habitats of supernatural creatures (132). While the fens are not explicitly mentioned as part of the natural scenery in the poems, Felix's Vita and the corresponding Anglo-Saxon Life are not the only occurrences in which fens are the home of monsters. For instance, Neville mentions "the joyless woods, wolves, and monsters" that can be found in the fens according to Beowulf (44). The monster Grendel comes "of more under misthleopum" ("from the moor under the misty cliffs," Beownlf 710)24 to attack the hall, and he flees after his defeat to the "fen-hop" ("land in the midst of fens," 764).

Overall, as Guthlac's choice of habitat is intimately connected with his saintly status, the devils' environment is likewise a part of their devilish status (128). This

\footnotetext{
${ }^{24}$ Note that mor can also be rendered as "mountain," which would mean that Grendel comes "from the mountain." The ambiguity of the term has been pointed out by Paul S. Langeslag; depending on the context in which it occurs, it can either denote "marsh" or "mountain" (122-23).
} 
leaves the landscape as an entity that seems to be altered and transformed by its inhabitants while simultaneously affecting them in turn. For instance, Siewers reads both the monsters in their oceanic setting in Beowulf and the demons in the fen-land in Guthlac accounts as "landscape narratives both of conquest and possession, and of the formation of cultural identity" (2). Accordingly, Guthlac's triumph over the demons and his subsequent appropriation of the land is interpreted as a "exorcism of an earlier indigenous culture" (14). The notion of a sacred geography that sees sites and abodes in the wilderness as filled with spiritual beings and deities of all kinds is not exclusive to Christianity; it is evident that the founders of early Christian monasteries exhibited a preference for sites that carried a ritual significance that predates the Christian and maybe even Anglo-Saxon settlement (Wickham-Crowley 99). Especially isolated or enclosed places of natural beauty such as springs, hills, caves, and groves were perceived as carrying a numinous aura of divinity (Caseau 24). In this context, the extraordinary attractiveness of certain locations-such as the beorg in the Gutblac texts that is sought after by both the holy man and the demons - can be explained by their inherent spiritual significance. As a result, Christian monks who were settling in areas known as pagan sanctuaries usually expected complications and conflicts with the remaining heathen gods who wanted to defend their territory (Caseau 33).

The landscape's pagan past and the effects of its conversion to a Christian environment find repeated expression in the texts. Remnants of the landscape's heritage include the already mentioned burial mound on which the saint chooses to dwell and the presence of the demons which Siewers regards as spirits of the site's native non-Christian population (25). The subject of ancestry and former inhabitants is explored in a general as well as in a more specific way: on the one hand, Guthlac identifies the demons as descendants of the rebellious fallen angels. Felix also classifies them as "sons of darkness, seed of Cain" (Colgrave 102). On the other hand, both the Anglo-Latin and the Old English hagiography describe the attacking devils as "British," i.e. as Celtic-speaking Britons, in a way that portrays them as savages and allies of the devil. Felix tells of one night when Guthlac is approached by "British hosts" who speak in "sibilant speech" that the saint is able to understand because he used to live in exile with them (Colgrave 111). The Old English Life also mentions this encounter: "pa gehyrde he mycel werod para awyrgedra gasta on bryttise sprecende; and he oncneow and ongeat heora gereorda, forpam he ærhwilon mid him wæs on wrace" (Gonser 136). ${ }^{25}$ Depicting the devils as spirits of the Brittonic inhabitants who dwelt in the region before the Anglo-Saxon settlement allows a reading of Guthlac's mission as a conquest and territorial appropriation of land. Conversion and missionary activities in foreign lands form an important part of the saints' responsibilities; the desire for the extension and stabilisation of God's kingdom is the driving force behind this pursuit

25 "Then he heard a troop of cursed spirits there speaking in British; and he knew and recognised their language, because he formerly was in exile with them." 
(Michelet 164). The creation of cults of local saints—which in turn supported the development of local churches - was encouraged by the idea of a universal mission that takes possession of new land in order to colonise it with a Christian population (Michelet 17). Therefore, it is important to take this context of conversion and colonisation into consideration for the analysis of the Guthlac poems.

Kelley M. Wickham-Crowley refers to Guthlac's conquest as the Christianisation of a pagan site which can be seen as "an exercise of religious control" and as an assertion of "real power over the land, over the past and over the imagination" (99). The transformation that the saint causes in the landscape can be seen as a process of conversion of its own. Hence the hermit's task is not to teach people about God, but to take possession of a barren land in order to purify and colonise it. Siewers even calls Guthlac's settlement and his conflict with the place's past residents which ends with their expulsion an "exorcism of quasi-human land spirits ... that marks cleansing and restoration" (36). In this understanding, heathendom affects both the people and the physical world, which is why a saint like Guthlac has to alter the realm around him physically as well as spiritually. Shook points out that the appeal of the beorg seems to increase the more Guthlac learns to appreciate it. The saint's attachment to his dwelling-place in Guthlac $A$ provokes a reaction in the devils that is notably different from their demeanour in Felix's Vita: while the demons in the Anglo-Latin hagiography are mostly interested in leading the saint astray and destroying his faith, the evil spirits in the Anglo-Saxon poem try to chase the saint away from the barrow in order to reclaim it as theirs. The fiends in Felix also try to persuade Guthlac to leave the wilderness and to return to human civilisation, but they do not assert ownership of the desert. The demons in Guthlac $A$ on the other hand consider themselves to be the legitimate owners due to the fact that they have been inhabiting the mountain before and longer than Guthlac (Shook 8-9).

The saint's power and authority become obvious not only in the changed quality of the landscape that expresses itself in the increased attractiveness and similarity to Paradise, but also in concrete changes and acts he performs. One example of this is the erection of the "Cristes rode," the cross of Christ (Guth.A 180a) in order to mark the land as belonging to God. In fact, the whole passage pictures Guthlac as a strong and capable warrior of God who undertakes the challenge of living in a remote and abandoned area and banishing the demons from this place. His conquest is described in almost ritualistic terms:

pær he mongum wearð

bysen on Brytene sippan biorg gestah.

Eadig oretta, ondwiges heard,

gyrede hine georne mid gæstlicum

wæpnum [and wædum], wong bletsade, him to ætstælle ærest arærde 
Cristes rode; pær se cempa oferwon

frecness fela. $(174 b-81 a)^{26}$

Once again, this emphasises the theme of spiritual warfare against the demonic powers that rule over the land he has chosen for himself. The sequence of his ascent, arming himself with "spiritual weapons," and erection of the cross is important for the saint's mission, because it reveals a process that overwrites the history and former quality of the landscape. Interestingly, the change in ownership is communicated in a Christian and in a pagan way: on the one hand, Siewers interprets Guthlac's acquisition of the burial mound as a way of marking one's territory that goes back to a prehistoric coding of landscape monuments (16-17). By constructing a barrow or occupying an already existing one, a person or a community would demonstrate their claim to be the legitimate landowner. On the other hand, Guthlac erects the cross as a symbol of Christianity, hence it serves as a visible proof of God's rule and power over the lands. Likewise, Guthlac appears as a "builder" ("bytla," 148b) when he constructs his halig ham ("holy home," 149). In this instance, Guthlac's dwelling-place is similar to a military outpost used to keep watch and stand guard against hostile forces; the poet also points out that the monk does not assert his claim to the lands for himself out of a desire for possession, but he appears as a safe-keeper for God's territory (148b-53a). The issues of legitimate ownership are addressed by dealing with the land as a property to which God and Guthlac stake a claim that is spiritual as well as proprietary. Needless to say, the demons detest the Christian entitlement to the location, but they do not emerge victorious from the conflict and even have to serve the holy man in the end. The saint's position as a builder who creates his own dwelling in the wilderness connects him to the architectural imagery surrounding the portrayal of heaven, while his role as a safe-keeper establishes him as a patron figure for the fens.

The Christian policy of settlement as it can be found in the poems at hand allows for only a specific kind of inhabitation. This is reflected in the fact that all previous attempts to populate the land have failed. Moreover, since they take part in each significant encounter in the battle for the beorg, one can also regard the angels as semi-permanent inhabitants that have been approved by God. As described before, they also participate in the transformation of the landscape, both indirectly by teaching the saint to appreciate it and directly by providing divine light and songs. In general, this reflects the notion of a landscape that has its own history of settlement, by mystic and spiritual beings. Consequently, the past of a landscape including its prior population can be recognised and inherited in form of traditions by any self-aware being. By emphasising the gradual and subtle

\footnotetext{
26 "There he became an example for many in Britain after he ascended the hill. The blessed warrior, brave in resistance, eagerly prepared himself with spiritual weapons and garments; he first set up Christ's cross at the station, and blessed the plain; there the warrior overcame a great number of dangers."
} 
changes that Guthlac causes in his environment, the poet portrays the replacement of the pagan and demonic presence with a Christian occupant as a wholesome kind of progress that improves the setting's quality and value. As he restores some of the Edenic features, Guthlac not only cleanses his own soul, he also contributes to a general process of civilisation and sacralisation that strongly affects the landscape. As Clarke puts it, "the conversion of hostile, wilderness landscape into a locus amoenus functions as a metaphor for spiritual conversion and cultivation, and for the establishment of peace and order" (Literary Landscapes 34). Moreover, in this transformation she sees a "localised enactment of a mythology that conflates cultivation of the land with spiritual cultivation" (51), which essentially means Christianity appears as a cultural imperialism that aspires to dominate, change, and ultimately displace pagan culture. This extends Guthlac's role from a simple warrior to a godly conqueror who sets out in order to introduce and establish a belief system that is presented as more rightful, advanced, and cultivated; simultaneously, he tames the landscape and transforms it into a more hospitable and enjoyable place. Once again, this shows that there is no fixed and immanent moral quality to the natural world; the landscape as it is presented in the Guthlac poems is only as demonic or divine as its inhabitants. Depending on the force in control, the same place can exhibit different features that characterise it as either paradisal or hellish. Thus the saint's endeavour to overcome the demons and take control of the land is not only a struggle for territory but also another way in which the cosmic conflict between good and evil is fought out by projecting it onto the landscape.

\section{Conclusion}

The earth as the transient home of humanity is not only spatially located between heaven above and hell below. As this paper has shown, the landscape itself is also often portrayed as morally ambiguous in the Old English Guthlac poems. Furthermore, the texts exhibit a preference for a fundamentally dichotomous representation of landscape that is based on heaven and hell as the ultimate Christian landscape archetypes. This is one of the reasons why an analysis of the poems' literary and theological influences enriches their interpretation, especially in terms of their attitudes towards nature. A preference for portraying symbolic landscapes alongside with representations of the physical world manifests itself in the creation of literary landscapes, which appear to be rather generic while being unmistakably influenced by the tension between Paradise and the underworld as scenic archetypes. The Guthlac poets frequently make use of these prototypical landscapes in their depiction of the saint's surroundings. They create a whole map of different locations by alluding to familiar and recognisable natural settings that already carry a distinct spiritual and moral meaning. The prime example of this would be heaven and hell as the two places of the Christian afterlife that constitute the best and 
the worst landscape possible, respectively. Hell appears as an actual place that is visited by Guthlac as part of his temptations, but it is also reflected in the earthly landscape and especially in its demonic inhabitants. Likewise, the stock images associated with heaven are used in order to demonstrate the mountain's positive transformation that is caused by the saint's presence. The association of greenness with the locus amoenus and Paradise is in this context surely one of the most important formulae that is used in order to convey the attractiveness of a place.

However, the surroundings that humankind experiences and occupies on earth are not actual realisations of either heaven or hell, but watered-down versions that display similar features. Yet the poets do not strictly adhere to the conventions used to convey these stereotypical settings, but they adapt them in order to add their own nuances. An example of this would be the modification of well-known tropes used in the hagiographies about the desert saints, such as the construction of a plain abode in a desolate and wild territory which is then frequently attacked by evil spirits. The fenlands that Guthlac chooses for his hermitage are described in a way that allows their classification as a vernacular version of the desert to which others saints such as Anthony have retreated. The wilderness of England not only shares topographical features such as its isolated vastness with the desert in hagiographical writings, but it also serves the same purpose: it enables an absolute retreat from worldly matters and the opportunity to realize an ascetic lifestyle free from comfort and pleasures. However, the authors give the saint's solitary dwelling-place a distinctive local twist by interlacing the rather generic wilds with descriptions of regional landmarks such as rivers and mountains, thereby creating a vernacular tradition of the desert located in medieval England. This paper has also demonstrated that light and darkness are closely connected with heaven and hell as important mediators of moral quality in the Guthlac poems. Light and darkness influence the ways in which Guthlac perceives and assesses his surroundings. While light signifies an increased quality of his (spiritual) life, its absence intensifies the hardships and struggles.

The Guthlac poems illustrate that the dichotomy of day and night is not merely a symbol of the passing of time that structures the natural world, but that it is a part of a symbolic pattern in which the duel between light and darkness is representative of the cosmic battle between good and evil. While the devils preferably dwell in dark and hidden places, Guthlac is protected by a holy light that comes in various forms to keep the darkness at bay. Likewise, the angels are portrayed as holy messengers who bring him both actual and spiritual light as a support when he is struck by terror and assaulted by wild demons at night. It is interesting to note how much Guthlac interacts with other beings, at least for someone who purposely chooses to live apart from his community. The frequent references to angels and demons vying for the holy man's soul suggest that a greater battle is fought in the wild. However, while the representation of animals in the Guthlac 
poems is influenced by biblical as well as hagiographical writings, the wildlife does not take sides, at least not as a uniform group.

The contrast between the wilderness and the city is surely a dichotomy that features prominently in the Guthlac poems. Although the poets emphasise that the isolation and the predominant lack of cultivation are some of the reasons why the monk chooses the specific surroundings as his hermitage, it is still evident that the truly desirable landscape is somewhat ordered and domesticated. Both the Garden of Eden and Jerusalem as the Heavenly City are places that are characterised by their orderliness and tranquillity. They are also cultivated sites in the sense that their creation is heavily influenced by man-made structures. For instance, the garden can be seen as a place of wilderness that is tamed in order to appease the demand for recreation and food. The same applies to the city and the hall as imaginations of heaven that offer security and companionship. Both of these places reflect a human desire to control and dominate one's surroundings. Following the Creation narrative, in which God places the world in the hands of humanity to make it theirs to inhabit, the submission of nature to Guthlac is tantamount to the restoration of what is perceived as the natural order. The imperialistic endeavour of winning the land for God and his Christian kingdom reinforces this reading. The expulsion of any pagan remains still attached to Guthlac's mound is necessary for the creation of a sanctified landscape that can accommodate Christian people. This, too, is an act of (re-)acquisition of what is perceived as an inherent right to a land and its population.

The Guthlac poems can also be read as meditations on the division of nature and culture. The conflict of man versus nature is a recurring theme in Old English literature; it is often a struggle of power between the vulnerable human being and the violent natural forces to which they are exposed. The Guthlac poems offer a version of this confrontation in which the natural world does not pose a deliberate threat to the man's well-being, yet it houses the devils and offers them ideal living conditions. It is the devils that are the real danger to Guthlac's soul, which makes the natural world at least part of Satan's scheme. Nevertheless, it is also a source of pleasure and delight for him: once he settles on the mountain, Guthlac soon starts to feel at home and the place grows dear to him. Guthlac's residence in the wilderness allows him to direct his attention inward. Besides his spiritual journey towards the heavenly kingdom, he also develops an understanding of the formerly despicable land and forms an emotional bond with the mountain. Against all odds, the saint achieves the seemingly impossible: the transformation of the previously bleak and uninviting landscape into a pleasant abode-which he does not inhabit for long, as the conversion of the site is shortly followed by his soul's journey to heaven. Still, he leaves a landscape behind that has been heavily affected by his presence; the altered state of the natural world signifies the fulfilment of his saintly mission. At the same time, the landscape also served its purpose as an instrument in the hands of God and Satan. The landscape may not have an autonomous 
morality, but a spiritual balance of powers lends it the capacity to manifest as either divine or demonic.

All in all, the written accounts of the English saint Guthlac show that the longing for authentic experiences in and with nature is not a modern phenomenon reserved for people who feel alienated and detached from the natural world and consequently their own human nature. Guthlac's desire to leave society behind in order to settle as a hermit on a mountain is certainly not based on a lack of closeness or exposure to the environment, as it is the case for many individuals today. Still, his desire to explore a coarse and undomesticated part of the planet, to challenge himself, and to push his limits in order to connect with the world around him in a way that is both physical and spiritual resonates with a contemporary audience. In the Christian mindset that influenced the Guthlac poems, Guthlac's actions can be seen as expressions of the immortal soul's restlessness on a transient earth; the insatiable longing for the true home-a paradisal place that has become rather obscure in its elusiveness-is an experience shared by all inhabitants of the post-lapsarian world. Yet the hermit's state at the close of his life is something that every Christian can hope for: as he reaches the end of his earthly existence, Guthlac's death marks the closure of his existence as a pilgrim and the beginning of his dwelling in the heavenly home.

\section{Works Cited}

Alexander, Dominic. Saints and Animals in the Middle Ages. Woodbridge, Suffolk: Boydell, 2008.

Anlezark, Daniel, ed. and trans. Old Testament Narratives. Cambridge, MA: Harvard UP, 2011.

Behaghel, Otto, and Burkhard Taeger, eds. Heliand und Genesis. 10th ed. Tübingen: Max Niemeyer Verlag, 1996.

Caseau, Béatrice. "Sacred Landscapes." Interpreting Late Antiquity: Essays on the Postclassical World. Eds. G. W. Bowersock, Peter Brown and Oleg Grabar. Cambridge, MA: Belknap Press of Harvard UP, 2001. 21-59.

Clarke, Catherine A. M. Literary Landscapes and the Idea of England, 700-1400. Cambridge: Brewer, 2006.

-. Writing Power in Anglo-Saxon England: Texts, Hierarchies, Economies. Cambridge: Brewer, 2012.

Checkering, Howell D. Jr., ed. and trans. Beowulf: A Dual-Language Edition. Garden City, NY: Anchor Books, 1977.

Colgrave, Bertram, ed. and trans. Felix's Life of Saint Guthlac. Cambridge: Cambridge UP, 1985. 
Glotfelty, Cheryll, and Harold Fromm, eds. The Ecocriticism Reader: Landmarks in Literary Ecology. Athens, GA: U of Georgia P, 1996.

Gonser, Paul, ed. Das angelsächsische Prosa-Leben des bl. Guthlac. Mit Einleitung, Anmerkungen und Miniaturen. Heidelberg: Winter, 1909.

The Holy Bible, Translated from the Latin Vulgate. New York: Dunigan, 1854.

Howe, John. "Creating Symbolic Landscapes: Medieval Development of Sacred Space." Inventing Medieval Landscapes: Senses of Place in Western Europe. Eds. John Howe and Michael Wolfe. Gainesville, FL: UP of Florida, 2002. 208-23.

Howe, Nicholas. "The Landscape of Anglo-Saxon England: Inherited, Invented, Imagined." Inventing Medieval Landscapes: Senses of Place in Western Europe. Eds. John Howe and Michael Wolfe. Gainesville, FL: UP of Florida, 2002. 91-112.

Howlett, David R., ed. Dictionary of Medieval Latin from British Sources. 17 vols. London: Oxford UP, 1975-2013.

Kabir, Ananya Jahanara. Paradise, Death and Doomsday in Anglo-Saxon Literature. Cambridge: Cambridge UP, 2001.

Langeslag, Paul S. "Monstrous Landscape in Beowulf." English Studies 96.2 (2015): 119-38.

Lee, Alvin A. The Guest-Hall of Eden: Four Essays on the Design of Old English Poetry. New Haven and London: Yale UP, 1972.

Magennis, Hugh. Images of Community in Old English Poetry. Cambridge: Cambridge UP, 1996.

Meyer, Robert T., trans. St Athanasius: The Life of Saint Anthony. Westminster, MD: The Newman Press, 1950.

Michelet, Fabienne L. Creation, Migration, and Conquest. Imaginary Geography and Sense of Space in Old English Literature. Oxford: Oxford UP, 2006.

Mitchell, W. J. T. "Imperial Landscape." Landscape and Power. Ed. W. J. T. Mitchell. Chicago: The U of Chicago P, 1994. 5-34.

Neville, Jennifer. Representations of the Natural World in Old English Poetry. Cambridge: Cambridge UP, 1999.

Patch, Howard Rollin. The Other World: According to Descriptions in Medieval Literature. New York: Octagon Books, 1970.

Piehler, Paul. The Visionary Landscape: A Study in Medieval Allegory. London: Edward Arnold Ltd, 1971.

Rapp, Claudia. "Desert, City, and Countryside in the Early Christian Imagination." The Encroaching Desert. Egyptian Hagiography and the Medieval West. Eds. Jitse Dijkstra and Mathilde van Dijk. Leiden: Brill, 2006.

Reichardt, Paul F. "Guthlac $A$ and the Landscape of Spiritual Perfection." Neophilologus 58 (1974): 331-38. 
Roberts, Jane, ed. The Guthlac Poems of the Exeter Book. Oxford: Clarendon Press, 1979.

Schulz, Günther, and Jürgen Ziemer. Mit Wüstenvätern und Wüstenmüttern im Gespräch: Zugänge zur Welt des frühen Mönchtums in Ägypten. Göttingen: Vandenhoeck and Ruprecht, 2010.

Scragg, D. G., ed. The Vercelli Homilies and Related Texts. Early English Text Society 300. Oxford: Oxford UP, 1992.

Siewers, Alfred K. "Landscapes of Conversion: Guthlac's Mound and Grendel's Mere as Expressions of Anglo-Saxon Nation-Building." Viator 34 (2003): 1-39.

Shook, Laurence K. "The Burial Mound in Guthlac A." Modern Philology 83.1 (1960): 1-10.

Smith, Macklin. Prudentius' Psychomachia: A Reexamination. Princeton, NJ: Princeton UP, 1976.

Spittler, Janet E. Animals in the Apocryphal Acts of the Apostles: The Wild Kingdom of Early Christian Literature. Tübingen: Mohr Siebeck, 2008.

Steen, Janie. Verse and Virtuosity: The Adaptation of Latin Rhetoric in Old English Poetry. Toronto: U of Toronto P, 2008.

Thorpe, Benjamin. Tha Halgan Godspel On Englisc: The Anglo-Saxon Version of the Holy Gospels. New York: Putman, 1848.

Tristram, Hildegard L. C. "Stock Descriptions of Heaven and Hell in Old English Prose and Poetry." Neuphilologische Mitteilungen 79 (1978): 102-13.

Weber, Robert, ed. Biblia sacra iuxta vulgatam versionem. 5th ed. revised by Roger Gryson. Stuttgart: Deutsche Bibelgesellschaft, 2007.

Wentersdorf, Karl P: "Guthlac A: The Battle for the beorg." Neophilologus 62 (1978): 136-42.

Wickham-Crowley, Kelley M. "Living on the ecg: The Mutable Boundaries of Land and Water in Anglo-Saxon Contexts." A Place to Believe in. Locating Medieval Landscapes. Eds. Clare A. Lees and Gillian R. Overing. University Park, PA: Pennsylvania State UP, 2006. 85-110. 